\title{
Inherent Natural Resistance of Woods to the Attack of the West Indian Dry-Wood Termite, Cryptotermes brevis Walker
}

\author{
George N. Wolcott ${ }^{1}$
}

\section{INTRODUCTION}

In July 1923 tests were initiated to determine The Comparative Resistance of Woods to the Attack of the Termite, Cryptotermes brevis Walker (3). ${ }^{2}$ With interruptions, they have been continued to date. The present report summarizes all the data which have been accumulated over the years, in some cases modifying results previously reported for some woods (9) as more extensive tests with other woods, and a perfected technique, have indicated more exactly their status in resistance to termite attack.

\section{NAMES OF TIMBERS USED}

Fundamental to this investigation was the accurate identification of the woods to be tested. For this, the entomologist must depend on the good offices not only of professional foresters, but also in some cases of cabinetmakers, who know only the common or accepted name for the raw materials with which they work. In the List and Index of this paper (pp. 271-310), the common name of the wood in the country of origin of the particular sample is given immediately after the scientific name. Possibly in a few cases this may be considered a more certain identification than the scientific name subseqently supplied, especially if the actual specimen was not available for critical examination by those who may be presumed to be more learned authorities. Elbert L. Little, Jr., Forester (Dendrology) of the U. S. Forest Service, has critically checked the scientific names, and for this the writer is most grateful, but in only a few cases had he seen the actual specimens of woods, for the identification of which he must not be held responsible.

As an indication of the confusion of names, which may and, in fact, often does occur, in Puerto Rico the name "guava" refers to the coffee shade tree Inga vera Willd., and not to Psidium guajava L., which produces the fruit that is the source of commercial guava jelly. Guayaba is the Puerto Rican name for Psidium guajava L.

The "Mora" of Puerto Rico is Chlorophora tinctoria (L.) Gaudichaud; the "Mora" of Trinidad is Mora excelsa Bentham, trees quite different botanically, as well as in their resistance to termite attack. Fustic is the

${ }^{1}$ Former Entomologist, Agricultural Experiment Station, University of Puerto Rico, Río Piedras, P. R. now retired at Remsen, N. Y.

${ }^{2}$ Italic numbers in parentheses refer to Literature Cited, p. 311. 
name in Trinidad for Chlorophora tinctoria, but the specimen officially authenicated by the Forest Department, Port-of-Spain, Trinidad, as being fustic, differs in depth of coloration from the rich, dark reddish-brown of the specimen from Puerto Rico, and is considerably less resistant to termite attack. A possible explanation is that the Trinidad specimen is of sapwood and the Puerto Rican is heartwood.

The redwood of Trinidad, officially authenticated as Guarea guara (Jacq.) P. Wilson, now in synonymy with Guarea trichilioides L., has a termite resistance of 48 as compared with that of the guaraguao of Puerto Rico: 70 , yet both are supposedly the same species of wood. In such cases of identity, or of synonymy, the evidence supplied by the feeding of the termites must be considered to be more reliable. These animals are more directly interested even than the professional forester or the systematic botanist. Their continued existence depends on the wood they are eating, and the entomologist at least comes to have greater confidence in their discrimination.

It might appear that the termites are not very exact about coniferous woods, which ordinarily can be assessed only on a plus or minus basis, but this is due to the varying gum content of the different samples of the wood, or even to variations in composition in different parts of the same sample. Bald cypress of the swamps of the Gulf Coast of the southern United States, Taxodium distichum (L.) Rich., is an extreme example. Samples from different localities, but all authentic and typical, show widely varying differences in fineness of grain and depth of coloration due to gum content and in resulting resistance to termite attack. The gummy resins of bald cypress are relatively nonvolatile, and indeed the term "the wood eternal" has been applied to the timber of this tree, but such volatile and evanescent constituents as camphor, for instance, impart only a temporary termite resistance. Of five kinds of camphor wood from Formosa tested and found initially repellent, only one, the true Cinnamomum Camphora (L.) Sieb., continues to be repellent (but not toxic) a year after the samples have been exposed to air.

The odor exuding from freshly cut timber of the Australian cypress pine, Callitris glauca $\mathrm{R}$. Brown, is not only horribly offensive to the human experimenter, but most profoundly affects the termites, being both toxic and repellent to them, so that to its wood was originally assigned a termite resistance rating of $100+$. The small samples, after years of exposure to the air, gradually lose this distinctive odor, at least on the outside, and are no longer toxic or repellent, but are still highly resistant to being eaten by the dry-wood termites.

Most highly toxic to termites, and to other insects also, is the Venezuelan and Trinidad wood Ryania speciosa Vahl, of which small samples are still 
so toxic after 5 years of exposure in the air that termites confined in the same petri dish die within a few hours. The wood is commercially used for the preparation of an insecticide: Ryania, of S. B. Penick \& Co., 50 Church Street, New York 8, N. Y., but unfortunately the tree is comparatively insignificant in size, and not only cannot be used in construction but apparently is not even used by cabinetmakers for making furniture. Pieces of the wood in a bookcase are not only termite-repellent, but keep out cockroaches, silverfish, and cigarette beetles, while the odor to human beings is unobjectionable, if perceptible at all.

The basis of termite-resistance in any wood is not high lignin content $(2,6)$, or hardness, but a specific chemical constituent, often present in only minute quantity $(10,11)$, but characteristic of each tree species, which happens to be distasteful, or repellent, or toxic to the termites. In limited amount, it is edible by the termites (when not toxic), but detection by the chemists of most of such constituents is still so recent that no information is available as to digestibility or otherwise.

Not only the presence but also the amount of the termite-repellent constituent of West Indian mahogany present in its heartwood determines its resistance to the attack of Cryptotermes brevis. Midway in the course of his studies of this extractive, Conrado F. Asenjo of the School of Tropical Medicine in San Juan, found that the pieces of waste mahogany which he was obtaining from the furniture manufacturers contained little or none of this material. Upon discrete questioning, they admitted that they were not using lumber of the local species, Swietenia mahagoni Jacquin, which was no longer commercially available, but Honduras mahogany, Swietenia macrophylla King. As indicated by its scientific name, this is a genuine species of mahogany, somewhat softer to be sure than that which had previously been obtained from Hispaniola, but in appearance, ease of working, and in customer acceptance, equally desirable from the standpoint of the cabinetmaker. As experimental tests with the termites had previously shown, however, its heartwood was much more susceptible to termite attack, the rating for Swietenia macrophylla being 59, as compared with 80 for Swietenia mahagoni. This record anticipated Conrado F. Asenjo's chemical investigations, and gave added evidence that the substance which he was extracting was indeed the chemical responsible for the enviable reputation of the true West Indian mahogany.

Indeed, because of its well-merited reputation, the name "mahogany" has been used for other woods which merely look like Swietenia mahagoni. In regions where dry-wood termites do not occur, these woods may be equally desirable from the standpoint not only of the cabinetmaker but also of the purchaser. The names "Philippine mahogany" or "African mahogany" are possibly even more impressive, and certainly sound more exotic. In 
countries of the Temperate Zone, they might be no more readily eaten by the kinds of subterranean termites that can survive cold weather than are most of the endemic woods of the Temperate Zone. But these other socalled mahoganies are very susceptible to attack by Cryptotermes brevis, and prospective purchasers of furniture in the West Indies should be made to realize that the termite-resistance rating of Philippine mahogany, Shorea negrosensis Foxw., is only 33; of African mahogany, Khaya ivorensis Chev., 30, and of Dutch mahogany (from Surinam), Virola mycetis Pulle, 28. It is most unfortunate that the Dutch mahogany extensively used in Puerto Rico in recent years as a plywood is not treated with some one of the well-known repellent chemicals by the maker of the plywood during the process of manufacture and thus rendered at least moderately safe for tropical construction.

\section{THE SAMPLE}

Each sample of wood to be treated was listed with the date of acquisition under an accession number and the common name in the country of origin, and/or the scientific name as supplied by the donor. Some samples were obtained already cut up into pieces exactly the right size for test, but most of the material obtained might be of any size or shape, and often had to be carefully differentiated to exclude portions of sapwood in the finished samples. The standard 120-by-15 mm. petri dish allows plenty of head room for termites to crawl over, rest upon, and feed on wood samples a quarter of an inch thick, but the standard wood sample furnished by foresters is half an inch thick or more, and splitting it to half that thickness invariably proved to be difficult. Regardless of the original shape and size of the crude, bulk sample, for use in tests with termites it had to be cut into pieces like dominoes, not more than a quarter of an inch thick, and approximately an inch wide and an inch and a quarter long. Cabinetmakers are accustomed to satisfy the requests of their customers, and in every case supplied samples of exactly the length, width, and thickness specified, and exclusively of heartwood, even if they didn't know the scientific name of the wood and had difficulty in spelling the common name. If not adequately polished and sandpapered originally, these final test samples received not only final touches on all sides and edges, but slight beveling of all edges and corners. They were carefully examined to exclude those with knots, or any slight defect which might influence the selection of point of attack by the termite.

Cabinetmakers were requested to furnish 12 samples of this domino size, but this was a standard that could not be exacted of donors. If more than a dozen specimens of a species were supplied, or could be cut from the bulk sample, all not immediately discarded were labeled with the accession num- 
ber, even if only a few were eventually polished and sandpapered for test. If only a few suitable test samples were supplied, one could only give thanks for blessings received, and hope that they would prove adequate in number for the conclusion of the tests. It was usually possible, after a test in which the sample had been eaten, to sandpaper away the raised area around the gouge eaten by the termites, and relabel on the fresh, unbroken surface. In other cases, the single sample free of sapwood, knots, and imperfections in the grain might survive uneaten in numerous tests until the final decisive acceptance by the termites would pinpoint its position, with seven or eight uneaten alternative species of woods more resistant to termite attack, versus numerous others eaten and previously indicated as more susceptible.

In only a few instances was more than a single bulk sample of a species of wood obtained, but it must not be thought that this seriously affects the results here reported. Except in the case of the conifers of which the composition of the heartwood might and usually does vary widely, that of other kinds of wood would appear to be remarkably uniform. A commercial sample of East Indian teakwood, Tectona grandis L.f., for instance, proved to be almost exactly as resistant to termite attack as is the heartwood from trees grown in Trinidad. When a special economic study was being made of Cacao Motillo de Puerto Rico, Sloanea berteriana Choisy, fresh specimens of the wood submitted by the foresters received the same reception from the termites as did the original sample submitted years previously. The termites found no difference in different samples of Honduras mahogany and those of Dutch mahogany, hopefully submitted by exporters in the expectation that fresh samples might change the reception accorded to them by the termites.

Specimens of Saman, Pithecellobium saman (Jacq.) Genth., from Puerto Rico, Trinidad, and Panamá proved to be indistinguishable to the termites, which switched their attentions from one sample to another until finally all three samples were eaten in approximately the same amount. The termites confirmed the opinion of systematists that the Ausubo de Puerto Rico, Manilkara bidentata (A. DC.) Chev., at least as far as taste of the wood is concerned, is identical with the Bolletrie of Surinam, Manilkara nitida (Seese \& Moc.) Dubard, and differentiated specimens of these two woods from those of Massaranduba do Brasil, Manilkara Huberi (Ducke) Standl., which is considerably more resistant to their attack. Not only did the termites sharply differentiate between West Indian and Honduras mahogany, but their discrimination was equally marked in other genera of which several species were available for test: Andria, Coccoloba, Guarea, Tabebuia, Terminalia, and Vochysia.

In obtaining data on the amount of food eaten by termites, and on the efficiency with which this is turned into termite and how much becomes ex- 
crement, all 12 samples were weighed on a chemical balance. Of the pair having most nearly the same weight, the one weighing slightly more was selected for the test ( $(3)$. When these tests were discontinued, samples were no longer weighed, but all the early samples had the accession number punched into one surface. This proved to be a disturbing factor in the selection of a point for beginning of feeding by the termites. Fortunately, labeling with India ink is not noted by the termites, being entirely disregarded in the selection of a place where they will begin to eat. Thus all subsequent samples were labeled not only with the accession number but also with the common and/or scientific name as well, often making detection of feeding more immediately apparent. The standard size of petri dish used holds eight or nine such wood samples (12), depending on how accurately they have been cut to the desired size, and if they cannot be fitted into position easily, it is always possible to sandpaper off a corner, or to rearrange them until they do fit snugly into place.

\section{THE EXPERIMENTAL ANIMALS}

Obtaining an adequate and steady supply of Cryptotermes brevis Walker, the common dry-wood termite of the West Indies, was often a difficult problem. It depended on inducing family or friends, or property clerk, to discard infested articles of furniture when they still had a maximum termite population. Theoretically, colonies of termites should persist until the last bit of wood has been consumed without breaking the outside protective layer of paint, varnish, or untreated wood. Actually, because of extensive emigration of the winged adults, and also of failure of more nymphs to develop when the most desirable pieces of sapwood in an article of furniture have been consumed, actual possession of an infested piece of furniture might not be obtained until it had comparatively few live inhabitants. Breaking up an apparently promising article of furniture to find nothing there but heaps of the little, hard, excrement pellets, showing how many live animals must have once lived within it, was always a disappointing and frustrating experience. All too often, one would be notified of some article of furniture which had been discarded only the week before, but had been smashed in being thrown out and exposed to the elements, so that all the live inhabitants were gone, or dead, or removed by the ants, before it could be rescued. At times, more termites were suddenly and unexpectedly made available than could be used to advantage, for once the breaking-up of a piece of furniture was commenced, it proved to be essential to extract all the termites from it immediately, rather than risk their being attacked by omnipresent foraging ants finding entrance in the all too numerous new and unprotected openings in their tunnels. Despite the fact that they eat wood, termites are essentially soft-bodied creatures, easily injured by rough 
treatment in being removed from their burrows. If a tough piece of wood has to be chopped apart to obtain them, their dislodged bodies when untangled from heaps at the bottom of their tunnels were invariably lifeless by the next day.

Infestations in poorly bonded plywood are most desirable for obtaining the experimental animals with minimum or no injury. By peeling back the outer veneer layer hundreds may be uncovered at one time, and easily shaken loose for transfer to the petri previously prepared for their reception with wood samples all tightly wedged into place. A cabinetmaker specializing in replacing termite-infested plywood radio cabinets with new ones of mahogany proved to be a friend indeed. An infested bulletin board of Douglas fir plywood proved to have so many separate colonies as to supply successive increments for the tests. Most desirable of all was the mass infestation of the quarter-inch-thick, inch-wide slats of flamboyan intended for cutting up into smaller blocks for impregnation with repellent chemicals $(10,11)$. This was really an unexpected and unplanned rearing of the experimental animals, nonetheless welcome despite the fact that it put an abrupt end to the further tests of impregnation in well-seasoned lumber with new chemicals. Such slats could be broken across with ease and the termites shaken out with absolutely no observable physical injury, and one hopes with but little disturbance of their peace of mind. It was found that their diet of flamboyán wood, among the most susceptible of woods, by no means affected the promptness of their making a choice among the most resistant of woods, difficult as that is under any circumstances.

Season of the year does have an observable effect on how readily termites make a decisive choice. In the late spring, the seemingly aimless activity of the numerous winged adults which have attained maturity in the petri dish and are merely waiting for a favorable opportunity to escape, is obviously most disturbing to the nymphs, which for the immediate present at least, are destined to remain right where they are. Their principal occupation is merely to eat and grow, rather than to prepare to escape from the confines of the family tunnel, or the petri-dish test. One might as well let the winged adults out at once, and also exclude them from new tests inititated in the spring.

The somewhat lower temperatures of winter in the Tropics also have a decided retarding effect on the activities of termites, and during most of the time when the tests were in progress, these were conducted in a constanttemperature oven set at $90^{\circ} \mathrm{F}$. This was hardly essential in spring, summer, and autumn, but the oven was a convenient place to keep the petri dishes at any time, being both light-tight and inaccessible to foraging ants. The petri dishes were kept individually wrapped in paper towels, and all of them in addition were kept surrounded by a cloth towel in the oven. 


\section{THE TESTS}

No definite number of termite nymphs was used in the tests. Quite aside from the difficulty of counting any specific number of these active little entities moving off in all directions at once, the number available at any one time depended to such a large extent on accident: good fortune in obtaining infested articles of furniture. Mortality was a more or less constant factor in reducing their number in the tests, especially with the more resistant woods, and constant replenishment of small numbers was impractical. Ordinarily, approximately 200 well-developed nymphs, with accompanying soldiers, dealate adults and such few small nymphs as happened to be present in the colony in nature, were transferred into the petri dish at one time with the wood samples. Often the soldiers died in a few days, turning black all over. The small nymphs either grew up to be big nymphs, or if initially too small to survive without special care, also perished in a few days. The dealate adults to a greater or less extent diverted the attention of the nymphs from the serious business of eating, as the nymphs tended to cluster around the adults, regardless of their position on the most attractive block of wood or in a corner on the glass floor of the dish. At first, a fertile female might lay an egg or two within a few days after removal from the colony in nature, but ordinarily the adults did not survive in the petri dish more than a few days or weeks. Thus the test depended primarily on the well-grown nymphs, which ate with undiminished voracity if even one kind of susceptible wood was present in the test, but with obviously greater deliberation if only the most resistant woods were available.

Unless very much crowded, the nymphs remained on the blocks of wood and never attempted to climb the walls of the petri dish. They were thus very amenable to test and gave explicit answers when the conditions were not too difficult, but paid with their lives if none of the woods in the test could be eaten. It must always be kept in mind that the conditions of the test more or less resembled those of a military concentration camp: all members of the colony unceremoniously removed from their home in nature and placed in a glass cage subject to bright light and inspection at any time, with food ample in amount and variety, but becoming progressively less attractive as the eaten and preferred samples were replaced with others less desirable. Inspections might be made daily, and invariably were made within a few hours after being initiated, but might subsequently be neglected for days, and even weeks, if other work was pressing.

More tests could be initiated if the supply of termites was ample; if initial or subsequent mortality was heavy, the termites of two tests could be combined in a single dish. Initially, all the termites in a test were taken from a single colony in nature, but no excessive mortality developed when 
those from two colonies were combined, and, so far as could be observed, the members of the two combined colonies did not remain separated, but mingled as though from a single source.

If the wood samples in the test were of widely varying termite resistance, the experimental animals promptly clustered on the most desirable sample, and ate that one to the complete exclusion of all others. Within a few days it would be so extensively and decisively eaten that it could be removed and another sample put in its place. The new sample was placed in the adjoining lower half of another petri dish for making such a transfer, and one by one, the uneaten samples in the test were removed and placed in the new dish, while any termites that might be resting on them were brushed off with a camel's-hair brush. The new wood sample and the seven or eight others of the original test were carefully adjusted and wedged into place so as to fit snugly and not rattle about to the injury of the termites when the dish was being moved. Finally, only the most attractive wood sample, now covered with termites, remained in the old petri dish. This wood sample was placed on top of those in the new dish by gingerly inserting the arms of a forceps among the clustering termites, and any termites remaining in the old dish were transferred to the new. Those which persisted in clustering on the preferred wood sample were gradually brushed off, until all were safely back in substantially the same environment that had been changed in one particular only: a presumably less attractive wood sample having been exchanged for the one that the termites considered most desirable.

When two wood samples in a test are of approximately equal desirability, the experimental animals eat them in approximately equal amount. In the early tests when the wood samples had been weighed, the amount eaten could be readily determined exactly by comparison with the other one of the pair. One quickly learns from experience that the weight of the wood samples varies with the humidity of the air, and comparisons can be made only with the uneaten one of the pair, previously weighed and selected as being most nearly the weight of the sample used in the test. The weight of the check does not remain constant, and both the eaten and the uneaten member of the pair must be weighed in immediate succession to determine exactly how much the termites have eaten. In attaining full size, a termite nymph eats 8 to 10 times its live weight in wood, and 200 termites in a few days make an appreciable cavity in a small wood sample.

If two samples have been unequally eaten, it should be obvious that one is somewhat less susceptible to termite attack than is the other. Indeed, when attempting to induce the termites to make fine distinctions, three or more samples may be eaten in only slightly varying amounts. 


\section{THE RECORDS KEPT}

The preliminary records of the tests were lists of the woods used in each test, later supplemented by notes on which wood samples were used to replace the one or more eaten. Such records get to be very cumbersome and confusing as they accumulated, and subsequently summary card forms were printed, assigning one or more cards to each species of wood tested. The printed head of this summary card read as follows:

\section{Resistance to attack of West Indian DRY-WoOd Termite by}

Underneath this was written the common name and the scientific name of the wood, and inconspicuously in an upper corner, its accession number. One half of the remaining space of the card was headed: "More eaten than." Under this were listed the others woods more resistant to attack as shown by tests, and, as a key to finding the original note if needed for subsequent reference, the date on which the test with the samples of these woods terminated.

The remaining other half of the space on the card was headed: "Less eaten than." Here were listed the other woods more susceptible to attack, and the date on which each test with each wood was terminated. Entirely disregarding the accession numbers, these cards were arranged, and constantly rearranged, with those of the woods most resistant to attack on top, and with all the gradations in resistance down to those which were most susceptible to attack on the bottom. As records on the woods accumulated it became possible to arrange these summary cards more exactly and to compile preliminary lists $(4,5,7)$ of woods in the order of their resistance to termite attack.

\section{THE RESISTANCE RATINGS}

As the lists became longer, it was possible to assign termite-resistance rating numbers, somewhat arbitrarily it must be admitted, because they can be based on no absolute standards except at the upper end. The woods which are definitely toxic to termites, even when not eaten by them, but are merely present with others in the petri dish, and cause death within a few hours, must definitely be given a rating of $100+$, and those which are permanently avoided by termites, but are not toxic, a rating of 100 . As some substances, such as sugarcane bagasse and cellulose acetate, are even more attractive to termites than any wood tested, the lowest rating for woods must be more than 0 , and was arbitrarily placed at 20 .

Assigning 80 to West Indian mahogany reflects a compromise between general public opinion that the heartwood of genuine mahogany is immune to termite attack, and the experimental evidence that it is only highly resistant. A considerable number of other woods are somewhat to very much 
more resistant, in addition to the very few that are entirely immune. If the latter are assigned 100 , obviously mahogany must be graded somewhat lower, but it can be only a matter of opinion how much lower. There are no absolute gradations between the highest and the lowest, and the assignment of numbers is only a convenience showing relative resistance as compared with other woods tested.

As the specimens of woods were acquired in a most haphazard manner, and even now hardly represent a fair sample of the woods of the world, it is nevertheless felt that the scarcity of woods with a high rating and the large number with a low rating give in reality substantially a true picture. The arbitrary assignment of 60 to Capá Prieto o Capá Amarillo de P. R., Cordia (or Cerdana) alliodora (R. \& P.) Cham., and of 40 to Laurel Sabino de Puerto Rico, Magnolia spendens Urban, was largely based on the local importance of these woods, Capá being a most desirable cabinet wood ordinarily considered reasonably resistant, and Laurel Sabino a beautiful dark-green wood which, unfortunately, is as susceptible to rot and decay when exposed to weather as it is to termites when used for furniture or interior trim.

The assignment of termite-resistance numbers greatly facilitated the proper placing new samples being tested, for by writing on the summary cards of each new sample the termite-resistance ratings of the other woods "More eaten than" and "Less eaten than," any item out of line was immediately disclosed, and appropriate tests could be made to correctly place and rectify the discrepancy. That is, as the data accumulated with more woods, every succeeding test was easier and could be more intelligently planned to give the desired information. Selection of woods for testing was narrowed down to those within a smaller margin of anticipated variation. Not only were termite-resistance ratings entered on the card for each kind of wood, but, in addition, were written in red crayon on the woods themselves. The wood samples could then be rearranged no longer according to the essentially meaningless accession numbers, but logically, so far as this investigation was concerned, according to termite resistance. Such a rearrangement made the selection of samples for testing with unknowns much simpler, but also resulted in less clear-cut results because the termites found greater difficulty in making choices between samples of so nearly the same desirability. This was additional proof of increasing accuracy in the assignment of the ratings, which, incidentally, is reflected in the presumed greater exactness of the present list as compared with those previously given.

It must be admitted that, statistically, the woods given in the following list may not be a fair sample geographically, or in the selection of specimen samples. In almost every case the forester submits samples of woods which he thinks the termites will not eat, but in practice, these prove to be com- 
mercially available woods, or those available to him at the time of selection. The cabinetmakers in Belém do Pará offered samples of what they considered to be the most desirable woods of those they had on hand from the Amazon region, and when later pressed for additional samples of other woods, explained that these were not as good as those previously submitted. But, if the best woods were made available in the Tropics, the same attempt was made to obtain the most desirable cabinet woods in Hawaii and in the United States. Thus the selection is not truly random, but is definitely weighed in favor of the better woods. If this indicates barely a sixth of the woods very resistant, and a quarter resistant, one must conclude that the number of susceptible woods would only be increased if additional samples were tested.

While it is possible that the woods most resistant to the attack of Cryptotermes brevis are also resistant to the attack of other termites, this is merely an assumption that may not be borne out by the facts. Such inherent natural resistance to being eaten by dry-wood termites is explicit for this kind of termite only under the conditions normal for its existence, and does not necessarily apply to subterranean and other species. The ominipresence of the "comején", Nasutitermes costalis Holmgren, on the trunks of flamboyán along Puerto Rican roads is a matter of common observation, but nests of this species have also been observed repeatedly on live and vigorous trees of West Indian mahogany.

In the teak forests of Java, L. E. G. Kalshoven (1) reported Neotermes tectonae Damm. colonies thriving in living trees of East Indian teak, Tectona grandis L.f., and colonies of Microtermes, Coptotermes, Odonototermes, and Eutermes feeding on the sapwood of girdled or felled teak trunks. Even though termites are tropical insects, the wood of some few trees of the Temperate Zone may contain substances which, experimentally impregnated in flamboyán wood in sufficient quantity, have been proven to confer immunity to dry-wood termite attack: pinosylvin monomethyl ether of Scotch pine, and taxifolin in Douglas fir $(10,11)$. But in the great majority of cases it is the trees of the Tropics of which the wood is most permanently resistant to dry-wood termite attack, while that of trees growing in the coldest regions of the world, Sitka spruce of Alaska, and Humboldt's willow of coastal Perú and Chile, which are most susceptible to destruction.

This could only be suspected from the first woods which were tested (4), consisting of local species readily available in Puerto Rico, and equally common species of the continental United States. It became more obvious later in the much more extensive compilation of additional woods of Puerto Rico and the United States, as well as many others from British Guiana (Demerara) and the Amazon delta region $(5,7)$. The subsequent acquisition of specimens from the countries of Central America and Panamá (8), 
Dutch Guiana (Surinam), Trinidad, Hawaii, the Gold Coast of Africa, and India gave little further proof in indicating any such obvious relationship.

During the winter of 1953-4, J. Ives Townsend of the University of Tennessee, toward the end of his stay at the Universidad do Río Grande do Sul, Porto Alegre, sent 17 specimens of accurately identified woods from the most southern portion of Brazil. It might be explained that Porto Alegre occupies a portion of the Southern Hemisphere comparable to that in the Northern Hemisphere of the Gulf Coast States on the United States. In this region of the United States, only two trees resistant to insect attack and fungus decay occur: osage orange and gummy bald cypress. It is quite possible that Río Grande do Sul may have some endemic trees comparable to these, but of the 17 samples submitted, all have a status more nearly comparable to Sitka spruce and the other conifers and hardwoods of the northern United States. It may be argued that there are no termites, or at least no dry-wood termites, outside of the Tropics or semi-Tropics, and thus the need for protection against their attack is unnecessary. But the dry-wood termites do not attack living trees; thus resistance to dry-wood termites has no survival value to any species of tree. Indeed, with the advent of man, with adequate tools and sufficient intelligence to cull the forests of the more desirable trees, but with foresight as yet insufficiently developed to purposely favor such trees, mahogany and lignum-vitae and Demerara greenheart and all the other most desirable species of the tropical forest are exposed to the danger of early destruction that less favored trees avoid.

\section{WOODS LISTED IN DESCENDING ORDER OF RESISTANCE}

TOXIC OR REPELLENT WOODS, TOTALLY TO VERY RESISTANT

Ryania speciosa Vahl; Bois L'agli of Trinidad, Aguacero, Cieza o Guarikama de Venezuela: Not repellent but still toxic after 5 years exposure in the air: $100+$.

Cinnamomum Camphora (L.) Sieb. of Formosa: Repellent after 1-year exposure in the air: 100.

(Callitris glauca R. Brown; Australian Cypress Pine: Not toxic, initially repellent, after 5-year exposure to the air no longer repellent but still very resistant: 71).

Amyris elemifera L.; Tea de Guánica, P. R., Bois Chandelle d'Haiti; Torchwood: 100.

Guaiacum officinale L.; Gaïac d'Haiti, Guayacán de R. D. y P. R., Lignumvitae: 100; SAP: 58.

Taxodium distichum (L.) Rich.; very gummy, fine-grained Bald Cypress from Palatka, Fla.: 100.

Brosimum paraense Huber; Muirapiranga do Brasil, Cardinalwood of Demerara: 99. 
Platymiscium Ulei Harms (= P. paraense Huber); Macacaúba do Brasil, Yama Rosewood: 98.

Zollneria guianensis Aubl.; Letterwood or Tibikushi of Demerara: 96.

Nectandra sp. (not Ocotea rubra); Wane of Surinam: 96.

Tabebuia capitata (Bur. \& Schum.) Sandw.; Hakia Greenheart from Demerara: 95.

Chloroxylon swietenia DC.; Indian Satinwood from Africa: 95.

Aniba ovalifolia Mez; Yellow or Garl Silverballi from Demerara: 94.

Plathymenia reticulata Bentham; Vinhatico do Brasil: 93.

Licaria canella (Meissn.) Kostern.; Brown Silverballi from Demerara: 93.

Chlorophora excelsa Bentham \& Hook f.; Iroko from Africa: 92.

Ocotea rodiaei (Schomb.) Mez; Demerara Greenheart, Bibiru: 91.

Maclura (or Toxylon) pomiferum (Raf.) Schneider; Osage Orange, Bois d'Arc of U.S.A.: 90.

Hymenaea courbaril L.; Algarrobo de P. R. y R. D., Courbaril, West Indian Locust: 89.

Chlorophora (or Morus) tinctoria (L.) Gaud.; Mora de P. R., Dyer's Mulberry: 88. — Fustic of Trinidad: 65 (possibly SAP).

Montezuma speciosissima Sessé \& Moc.; Maga de P. R.; 87.

Trichilia hirta L.; Ramoncillo de Faro de Cabo Rojo, P. R., Guaita, Broomstick: 86; SAP: 61.

Fagara macrophylla (Oliv.) Engler; from Africa: 85.

Intsia bijuga (Coteber.) Kuntze; Ipil of the East Indies: 85.

Trichilia pallida Sw.; Caracolillo de Guánica, P. R., Ramoncillo de R. D.: 84.

Prunus occidentalis Sw.; Almendrón de P. R. y R. D., Amandier d'Haiti, Cujani de Cuba: 84.

Eschweilera Sagotiana Miers; Common or Black Kakeralli of Demerara: 83. Krugiodendron ferreum (Vahl) Urban; Palo de Hierro de P. R. y R. D., Bois de Fer d'Haiti: 83.

Mora Gonggrijpii (Kleinh.) Sandw.; Morabukea of Demerara: 82.

Erythroxylon areolatum L.; Sapo Blanco de P. R., Poirier d'Haiti, Aroba de Cuba: 81.

Manilkara Huberi (Ducke) Standl.; Massaranduba do Brasil: 81.

Tectona grandis L.f.; East Indian Teak (material also from Trinidad): 80; SAP: 50.

Swietenia mahagoni Jacq.; Caoba de P. R. y R. D., Acajou d'Haiti, West Indian Mahogany: 80; SAP: 58.

\section{RESISTANT WOODS}

Vouacapoua americana Aubl.; Acapú do Brasil: 79.

Taxodium distichum (L.) Rich.; fine-grained, less gummy Bald Cypress from Ponchatoula, La.: 79. 
Bowdichia nitida Benth.; Sapupira o Sucupira do Brasil: 79.

Pinus occidentalis Sw.; Bois Pin d'Haiti, Pino de R. D., West Indian Pine: 78.

Andira surinamensis (Bondt.) Splitg.; Kuraru or Bat Seed of Demerara: 77. Goupia glabra Aubl.; Cupiúba do Brasil, Kabukalli of Demerara: 77.

Diplotropis purpurea (Rich.) Amsh.; Tatabu of Demerara: 77.

Bucida buceras L.; Ucar de P. R., Bois Gris-gris d'Haiti, Black Olive, Gregory: 75; SAP: 56.

Lecythis paraensis (Huber) Ducke; Castanha Sapucaia do Brasil, Monkey Pot of Demerara: 75.

Ocotea sp. from Panama, Aguacatillo: 74.

Fagara trinitensis (Williams) J. S. Beard; Bosoo of Trinidad, l'Epinet: 74.

Turpinia paniculata Vent.; Cedro Hembra o Avispillo de P. R.: 73.

Stahlia monosperma (Tul.) Urban; Cóbana Negra de P. R., Caobanilla de R. D.: 73.

Coccoloba rugosa Desf.; Ortegón de P. R.: 72.

Peltogyne pubescens Benth.; Kuroburelli or Purpleheart of Demerara: 72. Fagara (or Zanthoxylum) flavum Vahl.; Aceitillo de P. R., Satinwood: 72. Acacia (or Vachellia) farnesiana (L.) Willd. \& Arn.; Aroma de P. R.: 72. Tabebuia serratifolia (Vahl) Nicholson; Pau d'Arco do Brasil: 72.

Lysiloma latisiliqua (L.) Benth.; Caracoli de R. D., Tavernon d'Haiti, Sabicú de Cuba: 72.

Callitris glauca R. Brown; Australian Cypress Pine: initially repellent, after 5-year exposure: 71 .

Homalium racemosum Jacq.; Caracolillo de P. R., Tostado: 71.

Pimenta racemosa (Mill.) J. W. Moore (or Amomis caryophyllata (Jacq.)

Krug \& Urban); Ausú de P. R., Limoncillo, Pimienta, Bay Rum tree: 71.

Vochysia Melinonii Beckman; Wane Kwarie of Surinam: 71.

Terminalia amazonia (Gmel.) Exell.; Amarillo o Guayabón de Panamá: 70. Albizzia procera (Roxb.) Benth.; Albizia de P. R.: 70.

(Albizzia lebbeck (L.) Benth.; Acacia Amarilla de P. R., Tcha-tcha d'Haiti: untested).

Guarea trichilioides L.; Guaraguao de P. R.: 70.

Buchenavia capitata (Vahl) Eichl.; Granadillo de P. R., Bois Margot d'Haiti: 69.

Gossweilerodendron balsamiferum Harms from Africa: 69.

Anacardium excelsum (Bert. \& Balb.) Skeels; Espavél o Espavé de Panamá: 68.

Peltogyne Lecointei Ducke; Pau Roxo da Terra Ferme do Brasil: 68.

Euxylophora paraensis Huber; Pau Amarello do Brasil, Brasilian Satinwood: 68 .

Chamaecyparis obtusa Sieb. \& Zuc.; from Formosa: Originally repellent, after 1 year exposure to air: 67. 
Enterolobium cyclocarpum (Jacq.) Gris.; Guanacaste de Nicaragua: 67.

Coccoloba grandifolia Jacq.; Moralón de P. R.: 66.

Santalum freycinetianum Gaud.; Sandalwood of Hawaii: 66.

Caryocar brasiliense Camb.; Piquiá do Brasil, Butternut Tree: 65.

Terminalia arjuna Wight \& Arn.; Arjuna of India: 65.

Pithecolobium (or Pithecellobium) racemosum Mez; Angelim Rayado do

Brasil, Surinam Snakewood: 64.

Distemonanthus benthamianus Baill.; from Africa: 64 .

Humiria balsamifera Aubl.; Umiri do Brasil, Tauroniro of Surinam: 63.

Guarea glabra Vahl; Carimbo of Trinidad: 63.

Swartzia leiocalycina Benth.; Wamara of Demerara: 62.

Licania densiflora Kleinh.; Marishiballi of Demerara: 62.

Cedrela odorata L.; Cedro de P. R., West Indian Cedar: 61 .

Antidesma platyphyllum Mann; Hame or Haa of Hawaii: 61.

Ocotea acutangula Mez; Louro Tamancao do Brasil: 60.

Cariniata pyriformis Miers; Albarco de Colombia, Bacú de Venezuela: 60.

Platonia insignis Mart.; Bacury do Brasil, Pakui or Wild Mammee Apple

of Demerara: 60.

Robinia pseudoacacia L.; Black Locust of U.S.A.: 60.

Peltogyne porphyrocardia Griseb.; Purpleheart of Trinidad: 60.

Cordia (or Cerdana) alliodora (Ruiz \& Pav.) Cham.; Capá Prieto o Capá Amarillo de P. R., Spanish Elm of Jamaica, Bois Soumis d'Haiti, Cypre of Trinidad: 60 .

\section{LESS SUSCEPTIBLE WOODS}

Mezilaurus itauba (Meissn.) Taub. (= Sylvia Duckei A. Samp.); Itaúba do Brasil, Tapinhoam: 59.

Swietenia macrophylla King; Caoba de Méjico, Honduras Mahogany: 59;

SAP: 50.

Syncarpia laurifolia Ten.; Australian Turpentine: 59.

Manilkara (or Mimusops) bidentata (A. DC.) A. Chev.; Ausubo de P. R.,

Balata of Trinidad, Bolletrie of Surinam: 58.

Baikiaea plurijuga Harms, from Rhodesia, East Africa: 58.

Loxopterygium Sagotti Hook f.; Hububali of Demerara: 57.

Eucalyptus micrococera F. Muell.; from New South Wales and Queensland:

57.

Ocotea rubra Mez; Louro Vermelho do Brasil, Determa or Teteruma of

Demerara: 57.

Ocotea canaliculata (Rich.) Mez; Hariraru or White Silverballi of Demerara:

57.

Pithecellobium (or Samanea) saman (Jacq.) Benth.; Samán de P. R., Cenicero de Panamá, Saman of Trinidad: 57.

Qualea sp.; Appelquali of Surinam: 57. 
Tetragastris Hostmannii (Engl.) Kuntze; Salie of Surinam, Haiowaballi of Demerara: 56.

Protium heptaphyllum March; Breu Vermelho do Brasil: 56.

Eperua falcata Aubl.; Soft Wallaba of Demerara: 56.

Pouteria demerarae Sandw.; Asipoko of Demerara: 56.

Vochysia tetraphylla (G.F.W. Mey.) DC.; Iteballi of Demerara: 56.

Chamaecyparis nootkatensis (D. Don.) Spach; Yellow Cedar: 55.

Pinus echinata Mill.; Southern Yellow Shortleaf Pine: 55 \pm .

Pinus monticola Dougl.; Western White Pine: 55士.

Pinus palustris Mill.; Southern Yellow Pine: 55士.

Pinus ponderosa Laws.; Western Yellow Pine: 55土.

Pinus strobus L.; Northern White Pine: 55土.

Aspidosperma australe Muell. Arg.; Guatanbú o Piquiá de Río Grande do Sul, Brasil: 55.

Pseudotsuga menziesii (Mirb.) Franco; Douglas Fir: 55; SAP: 49.

Sequoia sempervirens (D. Don.) Endl.; California Redwood: 54.

Taxodium distichum (L.) Rich.; fine-grained but not gummy Bald Cypress: 54; SAP: 38.

Sloanea berteriana Choisy; Cacao Motillo de P. R., C. Roseta, Cacaillo, Motillo: 53; SAP: 46.

Andira inermis (W. Wright) H.B.K.; Moca de P. R., Angelin of Trinidad, Bois Palmiste d'Haiti: 52.

Magnolia portoricensis Bello; Mauricio o Burro de P. R.: 52.

Laugeria resinosa Vahl.; Aquilón de P. R.: 52.

Metrosideros polymorpha (Gaud.) Rock; Ohia Lehua of Hawaii: 52.

Sophora chrysophyllata (Salisbury) Seeman: Mamani of Hawaii: 52.

Petitia domingensis Jacq.; Capá Blanco de P. R. y R. D., Bois d'Ortie d'Haiti, Fiddlewood: 51.

Cordia Goeldiana Huber; Freijo do Brasil, Brasilian Walnut: 51.

Juniperus gracilior Pilger; Sabina de R. D.: 50.

Cedrela toona Roxb.; Cedro toona de R. D.: 50.

Rhizophora mangle L.; Mangle Colorado de P. R., Red Mangrove: 50; SAP: 41.

Prosopis juliflora (Sw.) DC.; Bayahonda de P. R., Mesquite: 50.

\section{MORE SUSCEPTIBLE WOODS}

Chamaecyparis formosensis Matsum.; from Formosa: Initially repellent, after 1-year exposure in the air: 49 .

Juniperus virginiana L.; Cedar, Red Cedar, Pencil Cedar, Juniper of U.S.A.: 49.

Mora excelsa Benth.; Mora of Trinidad and the Guianas: 49 .

Pleurothyrium cuneifolium Nees; Louro Abacate do Brasil: 49. 
Cunninghamia sinensis R. Brown; from Formosa: Initially repellent, after 1-year exposure in the air: 48.

Acacia koa Asa Gray; Hawaiian Koa: 48.

Micropholis chrysophylloides Pierre; Leche Prieto de P. R.: 48.

Ocotea leucoxylon (Sw.) Maza; Laurel Geo de P. R., Geo-geo: 48.

Ocotea Wachenheimii R. Ben.; Silverballi or Keriti of Demerara: 48.

Guarea guara (Jacq.) P. Wilson; Redwood of Trinidad: 48.

Hyeronima (or Hieronyma) clusioides (Tul.) Muell. Arg.; Cedro Macho de P. R.: 47.

Hyeronima (or Hieronyma) laxifolia Muell. Arg.; Suradan of Demerara: 47. Eschweilera corrugata (Poit.) Miers; Wena Kakeralli of Demerara: 47.

Cinnamomum micranthum Hay; from Formosa: Initially repellent, after 1-year exposure in the air: 47.

Catalpa longissima (Jacq.) Sims; Haitian Oak, Chêne Haitien, Bois Chêne d'Haiti, Roble de R. D.: 47; SAP: 45.

Cryptocarya Mandioccana Meissn.; Canela do Folha Redonda do Río Grande do Sul, Brasil: 46.

Aspidosperma excelsum Benth.; Yaruru of Demerara: 46.

Araucaria angustifolia (Bert.) Kuntze (= A. brasiliana A. Rich.); Pino Vermelho do Brasil, Paraná Pine: 46.

Linociera (or Mayepea) domingensis (Lam.) Knobl.; Hueso Blanco de P. R., Tarana de R. D., Cayepon d'Haiti, Wild Cocoplum: 46.

Pouteria (or Lucuma) multiflora A. DC.; Jácana o Acana de P. R.: 46

Qualea dinizii Ducke; Wirsiwirsi, Kwalie of Surinam: 46.

Nectandra sp.; Harde Pisie of Surinam, Blakka Pisie, Keretiballi of Demerara: 46.

Tetragastris balsamifera (Sw.) Kuntze; Masa de P. R., Amacey de R. D., Bois Cochon d'Haiti: 45.

Symphonia globulifera L. f.; Hooglandmataki of Surinam, Manniballi of Demerara: 45.

Conocarpus erectus L.; Mangle Botón de P. R., Paletuvier d'Haiti, Buttonwood: 45.

Rauwolfia tetraphylla L. ( $=R$. nitida Jacq.); Palo de Muñeca de P. R., Bois Lait Femelle d'Haiti, Milk Bush: 45.

Platymiscium trinitatis Benth.; Roble of Trinidad: 45.

Pithecellobium jupunba (Willd.) Urban; Puni of Trinidad: 45.

Bambusa tuldoides Munro; Tulda Bamboo (inside): 45.

Hibiscus tiliaceus L. (= Paritium tiliaceum A. Juss.); Mahoe of Jamaica (grown in P. R.), Majagua or Emajagua de P. R., Coton Marron o Mahaut Franc d'Haiti: 45; SAP: 44.

Cyrillia racemiflora L.; Palo Colorado de P. R., Leatherwood of U.S.A.: 45. Vochysia maxima Ducke; Quaruba o Cedro Rana do Brasil: 44. 
Hyeronima (or Hieronyma) caribaea Urban; Tapana of Trinidad: 44.

Dicorynia guianensis Amsh.; Basralocus of Surinam, Angélique d'Cayenne, Angelico do Pará do Brasil: 44.

Pterocarpus draco L. (= P. Ulei Harms); Bébé of Surinam, Sangre de Drago: 44.

Sclerolobium melinonii Harms; Witte Djedoe of Surinam: 44.

Juglans nigra L.; Black Walnut of U.S.A.: 44.

Bombacopsis quinatum (Jacq.) Dugand; Pochote, Cedro Espino de Nicaragua: 44.

Thuja plicata Donn; Western Red Cedar of U.S.A.: 44.

Anacardium sp.; Marañón de Ecuador: 44.

Terminalia ivorensis Chev.; from the Gold Coast, West Africa: 43.

Anacardium occidentale L.; Pajuíl de P. R., Acajou d'Haiti, Cajú do Brasil, Cashew: 43.

Citharexylum fruticosum L.; Péndula de P. R. y R. D., Old Woman's Bitter: 43.

Quercus alba L.; White Oak of U.S.A.: 41.

Vitex divaricata Sw.; Higüerillo de P. R., Lizardwood, Black Fiddlewood: 42.

Qualea albiflora Warm.; Mandioqueira do Brasil, Gronfoloe of Surinam: 42. Calophyllum brasiliense Camb.; Santa María de Panamá: 42.

Juglans cinerea L.; Butternut of U.S.A.: 41.

Lithraea brasiliensis March; Aroeira Bugre do Río Grande do Sul, Brasil: 40.

Myrciaria delicatula (DC.) Bg.; Camboim Branco do Río Grande do Sul, Brasil: 40.

Liriodendron tulipifera L.; Yellow Poplar of U.S.A.: 40.

Magnolia splendens Urban; Laurel Sabino de P. R., Sabino: 40.

VERY SUSCEPTIBLE WOODS

Artocarpus altilis (Parkinson) Fosberg (= A. communis Forst.); Pana de

P. R., Palo de Pan, Panapén, Breadfruit, Arbre á Pain: 39; SAP: 25.

Phyllostylon brasiliensis Cap.; Melón de Nicaragua, Jatía de Cuba, Bois

Blanc d'Haiti, Baitoa de R. D., San Domingo Boxwood: 39.

Cedrela fissilis Vell.; Caroba do Río Grande do Sul, Brasil: 39.

Calophyllum lucidum Benth.; Galba of Trinidad: 39.

Guadua latifolia (Humboldt \& Bonpl.) Kunth; inner layer of Ecuadoran

Giant Bamboo: 39.

Melisoma Herberti Rolfe; Aguacatillo de P. R.; Cacao Bobo de R. D.: 38.

Tsuga canadensis (L.) Carr.; Eastern Hemlock of U.S.A.: 38.

Sorocea ilicifolia Miq.; Sinche do Río Grande do Sul, Brasil: 38.

Larix occidentalis Nutt.; Tamarack or Larch, U.S.A.: 38. 
Casuarina equisetifolia L.; Australian Pine or Beefwood, Pino Australiano (grown in P. R.) : 37 .

Calophyllum brasiliense Camb., var. antillanum (Britton) Standl.; María de P. R. y R. D., Dame-Marie d'Haiti: 37.

Micropholis garcinifolia Pierre; Caimitillo Verde de P. R.: 37.

Ocotea moschata (Meissn.) Mez; Nuez Moscada de P. R.: 36.

Pinus sylvestris L.; Scotch pine from Sweden: Periferal HEART: 36; Central HEART: 34; SAP: 27.

Carapa nicaraguensis C. DC.; Cedro Macho, Caobillo o Saba de Nicaragua: 36.

Carapa procera DC.; Krappa of Surinam, Andiroba do Brasil, Crabwood: 36.

Carapa guianensis Auld.; Crappo of Trinidad, Cedro Macho de Costa Rica: 36. (So far as the termites are concerned, these last three woods are all one species).

Roystonea (or Oreodoxa) borinqueña O. F. Cook; Palma Real de P. R., Royal Palm (interior): 35 .

Ilex nitida (Vahl.) Maxim; Hueso Prieto de P. R.: 35.

Ormosia Krugii Urban; Palo de Mato de P. R.; Palo de Peroniá: 35.

Elaeodendron xylocarpum (Vent.) DC.; Cocorrón de P. R., Coscorrón, Guayabote, Marble Tree, Nut Muscat: 35.

Calcygonium squamulosum Cogn.; Camacey Jusillo de P. R., Granadilla Cimarrona: 35.

Actinostemon concolor (Spreng.) Muell. Arg.; Larenjeira do Mato do Río Grande do Sul, Brasil: 35 .

Nectandra coriaceae (Sw.) Maza; Laurel Avispillo de P. R.: 35.

Tabebuia pallida Miers; Roble de P. R., Apamate of Trinidad, White Cedar, West Indian Boxwood: 34.

Genipa americana L.; Genipaporana do Brasil, Jagua de P. R., Géne-pas d'Haiti: 34.

Vismia macrophylla H.B.K.; Pienja of Surinam, Caopiá do Brasil: 34.

Shorea negrosensis Foxw.; Tanguile, Red Lanan, Philippine Mahogany: 33.

Eugenia Stahlii (Kiaersk.) Krug et Urban; Guayabota o Limoncillo: 33. Cassia (or Sciacassia) siamea Lam.; Casia Amarilla de P. R.: 33.

Guazuma ulmifolia Lam.; Guácima de P. R., Bois d'Orme d'Haiti, West Indian Elm: 33.

Ochroma lagopus Sw. ( = 0. pyramidale (Cav.) Urban); Guano de P. R., Coton Fleurs o Mahaudéme d'Haiti, Corkwood, Balsa: 33.

Sterculia pruriens (Aubl.) Schum.; Yahu or Maho of Demerara, Cochón d'Cayenne, Axixa o Pau Rei do Brasil: 32.

Sarcocephalus diderrichii de Wild.; Opepe of Gold Coast, Africa: 32.

Protium decandrum March; Purokai or Kurokai of Demerara: 32. 
Catostemma commune Sandw.; Baromalli or Adaurona of Demerara, Flambeau Rouge d'Cayenne: 32 .

Terminalia catappa L. ; Almendro de P. R., Amandiera des Indies, Zanmande, Indian or Malabar Almond: 32.

Calyptranthes concinna DC.; Camboim Branco do Río Grande do Sul, Brasil: 32.

Psidium guajava L.; Guayaba de P. R. y R. D., Gouyave d'Haiti, Guava: 32.

Carya glabra (Mill.) Sweet; Pignut Hickory of U.S.A.: 31.

Ficus retusa L. (= F. nitida Thunb.); Laurel de la India de P. R. y R. D.: 31; SAP: 21.

Hippomane mancinella L.; Manzanillo de P. R., Mancinillier o Pomme Zombi d'Haiti, Manchineel: 32.

Khaya ivorensis Chev.; African Mahogany: 30.

Coccoloba uvifera (L.) Jacq.; Uva de Mar o Uvero de P. R., Rasin la Mer d'Haiti, Seagrape: 30 .

Eucalyptus robusta Smith (grown in P. R.) : 30 .

Mammea americana L.; Mamey de P. R., Abricotier d'Haiti, Mammee, Mamey Apple: 30.

MOST SUSCEPTIBLE WOODS

Guettarda laevis Urban; Cucubano de P. R.: 29.

Dacryodes excelsa Vahl; Tabonuco de P. R.; Candlewood: 29.

Tamarindus indica L.; Tamarindo de P. R., Tamarin d'Haiti, Tamarind: 29.

Quercus rubra L., Red Oak of U.S.A.: 29.

Beilschmiedia (or Hufelandia) pendula (Sw.) Nees; Guajón de P. R., Aguacate Cimarrón, Cedro Macho, Palo Colorado: 29.

Ficus pumila L.; Yedra de P. R.: 29.

Liquidambar styraciflua L.; Redgum of U.S.A.: 29.

Copaifera officinalis L.; Balsam of Trinidad, Copaiba de R. D.: 29.

Ocotea spathulata Mez; Nemocá de P. R.: 29.

Hura crepitans L.; Javillo de P. R. y R. D., Sablier d'Haiti, Possentrie, Monkey Pistol, Sand-Box: 28.

Ficus elastica Nois.; Palo de Goma de P. R., Caoutchouc d'Haiti, Rubber Tree: 28.

Prunus serotina Ehrh.; Northern Black Cherry of U.S.A.: 28.

Byrsonima spicata (Cav.) L. C. Rich.; Maricao de P. R., Serrete of Trinidad: 28.

Coffea arabica L.; Café de P. R., Coffee: 28.

Schinus terebinthifolius Raddi; Pimienta do Brasil, Christmas Berry of Hawaii: 28. 
Inga vera Willd.; Guaba de P. R., Sucrin ou Poix Doux d'Haiti, Inga: 28. Inga laurina (Sw.) Willd.; Guamá de P. R., Jina de R. D.,: 28.

Ilex opaca Ait.; Holly of U.S.A.; 28.

Cecropia peltata L.; Yagrumo Hembra de P. R., Bois Trompette d'Haiti, Boschpapaia of Surinam, Ambaiba do Brasil: 28.

Triplaris surinamensis Chem.; Mierenhout of Surinam, Bois Fourmi ou Formigueira d'Cayenne: 28.

Virola mycetis Pulle (=V. surinamensis (Rol.) Warb.); Banak, Mahaban, Beciuba, Pientri, Baboen, Baboonhoodoo of Surinam, Dutch Mahogany: 28.

Luchea divericata Mart.; Acoita Cavalo do Río Grande do Sul, Brasil: 28. Borassus aethiopium Mart.; African Fan Palm of Gold Coast: 27.

Eucalyptus citriodora Hook; (grown in P. R.): 27.

Citrus sinensis (L.) Osbeck; China de P. R., Orange: 27.

Zanthoxylum martinicense (Lam.) DC.; Cenizo de P. R.; Espino Rubial, Ayua: 27.

Fraxinus americana L.; White Ash (grown in P. R.): 27.

Matayba domingensis (DC.) Radlk.; Negra lora de P. R., Doncella, Téa Cimarrona, Raton: 27.

Ocotea arechavaletae Mez; Canela Guaicá do Río Grande do Sul, Brasil: 27. Jacaranda semiserrata Cham.; Caroba do Brasil: 27.

Clusia rosea Jacquin; Cupey de P. R., Scotch Lawyer of Trinidad, Figuier Maudit d'Haiti, Pitch Apple, Strangling Fig.: 27.

Morus rubra L.; Mulberry (grown in Ohio, U.S.A.): 27.

Didymopanax morototoni (Aubl.) Dene. et Pl.; Yagrumo (o Grayumo)

Macho de P. R.: 27.

Nectandra Sintenisii Mez; Laurel Amarillo do P. R.: 27.

Nectandra coriaceae (Sw.) Griesb.; Laurel Avispillo de P. R.: 26.

Acer rubrum L.; Red Maple of U.S.A.; 26.

Metopium toxiferum (L.) Krug et Urban; Papayo de Mona, Cedro Prieto de P. R., Mancinillier d'Haiti, Poisonwood: 26.

Betula alleghaniensis Britton; Yellow Birch of U.S.A.: 26.

Hernandia sonora L.; Mago de P. R., Jack-in-the Box of Barbados, Toporite of Trinidad: 26.

Bambusa vulgaris Schrad.; Bamboo: 26.

Sterculia caribaea R. Br.; Mahoe of Trinidad: 26.

Ficus laevigata Vahl.; Jagüey de P. R.,: 26.

Spondias mombin L.; Jobo de P. R., Mombin Frane d'Haiti, Hog Plum: 25. Ceiba pentandra (L.) Gaertn.; Ceiba de P. R., Mapou d'Haiti: 25.

Tapirira marchandii Engl.; Duka of Demerara, Waramai of Surinam, Tapiriri d'Cayenne, Cedrohy, Tatapiririca do Brasil: 24. 
Simaruba (or Simarouba) amara Aubl.; Marupá do Brasil, Marouba of Trinidad, Brasilian White Pine: 24.

Simaba multiflora Juss.; Hachiballi of Demerara, Simaruba Mirim: 24.

Sapium laurocerasus Desf.; Hincha-huevos de P. R., Lecherillo, Tabeia: 24.

Quercus chrysolepis Liebm.; Cañon Oak of U.S.A.: 24.

Avicennia nitida Jacq.; Mangle Bobo o Mangle Negro de P. R., Manglier Noir d'Haiti, Salt Pond: 23.

Bursera (or Elaphrium) simaruba (L.) Sarg. (= B. gummifera L.); Almácigo de P. R., Chiboué d'Haiti, West Indian Birch: 23.

Cupania americana L.; Guara de P. R., Guarana de R. D., Bois de Satanier d'Haiti: 23.

Pinus taeda L.; Loblolly Pine of U.S.A.: 22.

Melia azedarach L.; Alilaila o Lilaila de P. R., Lilas de R. D. y d'Haiti, Chinaberry: 22.

Eugenia jambos L.; Pomarrosa de P. R., Pomme Rose d'Haiti, Rose Apple, Malabar Plum: 22.

Tabebuia ipe (Mort.) Standl.; Ipe Rojo do Río Grande do Sul, Brasil: 22. Nectandra saligna Nees; Canela Preta do Río Grande do Sul, Brasil: 22.

Cordia hypoleuca DC.; Louro do Río Grande do Sul, Brasil: 22.

Alchornea latifolia Sw.; Achiotillo o Palo de Cotorra de P. R., Bois Crapaud ou Bois Vache d'Haiti: 21.

Grevillea robusta Cunn.; Australian Silver Oak (grown in P. R.): 21.

Rollinia salcifolia Schlecht; Araticum do Río Grande do Sul, Brasil: 21.

Solanum auriculatum Ait.; Fuma Brava do Río Grande do Sul, Brasil: 20.

Salix Humboldtiana Willd. (= S. chilensis Molina); Sauce de P. R., Humboldt's Willow: 20.

Delonix (or Poinciana) regia (Bojer) Raf.; Flamboyán de P. R., Flamboyánt d'Haiti, Flametree, Royal Poinciana: 20.

Picea sitchensis (Bong.) Carr.; Sitka Spruce: 20.

\section{WOODS LISTED ALPHABETICALLY WITH INDICES OF RESISTANCE}

Abacate, Louro, do Brasil; Pleurothyrium cuneifolium Nees: 49.

Abricotier d'Haiti, Abricotiero; Mammea americana L.: 30.

Acacia (or Vachellia) farnesiana (L.) Willd.; Aroma de P. R., Casha,

Cashia of Bahamas, Huisache de Méjico: 72.

koa Asa Gray, var. hawaiiensis; Hawiian Koa: 48.

Acajoú d'Haiti; Anacardium occidentale L.; 43, or Swietenia mahagoni Jacquin: 80.

Acajoú blanc d'Cayenne; Simarouba amara Aubl.: 24.

Acana de P. R.; Pouteria (or Lucuma) multiflora A. DC.: 46. 
Acapú do Brasil; Vouacapoua americana Aubl.: 79.

Aceitillo de P. R.; Zanthoxylum flavum Vahl.: 72.

Acer rubrum L.; Red Maple: 26.

Acoita-cavalo do Brasil; Luehea divaricata Mart.: 28.

Actinostemon concolor (Spreng.) Muell. Arg.; Larenjeira do Mato do Brasil:

35.

Achiotillo de P. R.; Alchornea latifolia Sw.: 21.

Adaurona of Demerara; Catostemma commune Sandw.: 32.

African Mahogany; Khaya ivorensis Chev.: 30.

Fan Palm; Borassus aethiopium Mart.; 27.

Aguacatillo de P. R.; Melisoma Herberti Rolfe: 38 .

Aguacate de P. R.; Persea americana Mill.: 48.

Aguacate Cimarrón; Beilschmiedia pendula (Sw.) Nees: 29.

Aguacero de Venezuela; Ryania speciosa Vahl: still toxic after 5 years: $100+$.

Aguacatillo de Panamá; Ocotea sp.: 74.

Akoelie Kiererie of Surinam; Andira surinamensis (Bondt.) Splitg.: 77.

Albarco de Colombia; Cariniata pyriformis Miers: 60.

Albizzia procera (Roxb.) Benth.; White Siris: 75.

Alchomea latifolia Sw.; Achiotillo de P. R., Palo de Cotorra, Bois Crapaud,

Bois Vache d'Haiti: 21.

Alcornoque de Venezuela; Bowdichia nitida Benth.: 78.

Algarrobo de P. R.; Hymenaea courbaril L.: 89.

Alilaila de P. R.; Melia azedarach L.: 22.

Alligator pear; Persea americana Mill.: 48.

Alligatorwood; Guarea trichilioides L.: 70.

Almácigo de P. R.; Bursera simaruba (L.) Sarg.: 23.

Almecega do Brasil; Protium heptaphyllum March: 59.

Almendro de P. R.; Terminalia calappa L.: 32.

Almendrillo o Almendrón de Hispaniola y P. R.; Prunus occidentalis Sw.: 84.

Almesca do Brasil; Tetragastris Hostmannii (Engl.) Kuntze: 56.

Almond, Indian or Malabar; Terminalia catappa L.: 32 .

Amandier d'Haiti; Prunus occidentalis Sw.: 84.

Amandier des Indies; Terminalia catappa L.: 32.

Amarante d'Cayenne; Peltogyne pubescens Bentham: 72.

Amarillo de Panamá; Terminalia amazonia (Gmel.) Exell: 58.

Ambaiba do Brasil; Cecropia peltata L.: 28.

Amoeira Brava do Brasil; Chlorophora tinctoria (L.) Gaud.: 88.

(Amomis caryophyllata, Amomis grisea) Pimenta racemosa (Mill.) J. W.

Moore; Ausú de P. R., Auzú, Limoncillo, Pimienta, Bay Rum Tree,

Wild Cinnamon, Malagueta, Bois d'Inde Francais: 71. 
Amyris elemifera L.; Tea de P. R., Palo de Tea, Torchwood, Bois Chandelle d'Haiti: $100+$.

Anacardium excelsum (B. \& B.) Skeels; Espavé de Panamá: 68.

Anacardium occidentale L.; Cajuil (acepción castiza), Pajuil de P. R., Cashew, Acajoú d'Haiti: 43.

Anany do Brasil; Symphonia globulifera L.f.: 45.

Andira inermis (W. Wright) H.B.K. (= A. jamaicensis); Moca de P. R., Bastard Mahogany, Angelin of Trinidad and Jamaica, Bois Palmiste d'Haiti: 46.

surinamensis (Bondt.) Splitg.; Bat Seed, Kuraru of Demerara, Akoelie Kiererie, Saint Martin: 77.

Andiroba do Brasil; Carapa procera DC.: 39.

Angelim Rayado do Brasil; Pithecellobium racemosum Mez: 64.

Angelin of Trinidad and Jamaica; Andira inermis (W. Wright) H.B.K.: 46. Angelin of Demerara; Andira surinamensis (Bondt.) Splitg.: 77. Angélique d'Cayenne, Angelica do Pará; Dicorynia guianensis Amsh.: 44. Aniba ovalifolia Mez; Gale or Yellow Silverballi of Demerara: 94. Antidesma platyphyllum Mann.; Haa or Hame of Hawaii: 61 .

Appelquali of Demerara; Qualea sp.: 57.

Apple, Mammee; Mammea americana L.: 30.

Wild Mammee; Clusia rosea Jacq.: 30.

Aquilón de P. R.; Laugeria resinosa Vahl: 52. Aracary do Brasil; Sorocea ilicifolia Miq.: 38. Araticum do Brasil; Rollinia salicifolia Schlechl.: 21. Araucaria angustifolia (Bert.) Kuntze $=A$. brasiliana A. Rich.; Pino Vermelho do Brasil, Paraná Pine: 46.

Arbre á Pain d'Haiti: Artocarpus altilis (Parkinson) Fosberg: 39; SAP: 25. Arjuna of India; Terminalia arjuna Wight \& Arn.: 65.

Arobo o Arobillo de Cuba y R. D.; Erythroxylon areolatum L.: 81.

Aroeira Bugra do Brasil; Lithraea brasiliensis March.: 40.

Aroma de P. R.; Acacia farnesiana (L.) Willd.: 72.

Artocarpus altilis (Parkinson) Fosberg; Pana de P. R., Palo de Pan, Panapén, Breadfruit, Arbre á Pain d'Haiti: 39; SAP: 25.

Ash; Fraxinus americana L. (grown in P. R.): 27.

Asipoko of Demerara; Pouteria demerarae Sandw.: 56.

Aspidosperma australe Muell. Arg.; Piquia o Guatanbú do Brasil: 55.

excelsum Bth.; Yaruru of Demerara, Paddlewood: 46.

Australian Cypress Pine; Callitris glauca R. Brown: 71.

Oak; Grevillea robusta Cunn.: 21.

Pine; Casuarina equisetifolia L.: 37.

Turpentine; Syncarpia laurifolia Ten.: 59.

Ausú de P. R., Auzú; Pimenta racemosa (Mill.) J. W. Moore: 71. 
Ausubo de P. R.; Manilkara bidentata (A. DC.) Chev.: 58.

Avicennia nitida Jacq.; Mangle Bobo de P. R., M. Negro, M. Prieto, Manglier Noir d'Haiti, Black Mangrove, Olive Mangrove, Paletuvier, Salado de Panamá, Seite Cueros, Salt Pond: 23.

Avispillo de P. R.; Turpinia paniculata Vent.: 73.

Avocado, Avocat d'Haiti; Persea americana Mill.: 48.

Axixa do Brasil, Sterculia pruriens (Aubl.) Schum.: 32.

Ayua; Zanthoxylum martinicense (Lam.) DC.: 27.

Baboen of Surinam, Baboonhoodoo; Virola mycetis Pulle: 28.

Bacú de Venezuela; Cariniata pyriformis Miers: 60.

Bacury do Brasil, Bacoropari; Platonia insignis Mart.: 60.

Baikiaea plurijuga Harms from Rhodesia, East Africa: 58.

Baitoa de R. D.; Phyllosiylon brasiliensis Cap.: 40.

Balata de R. D., Colombia, Venezuela, Trinidad and Demerara; Manilkara bidentata (A. DC.) Chev.: 58.

Balata do Brasil; Manilkara Huberi (Ducke) Standl.: 81.

Bald Cypress; Taxodium distichum (L.) Rich.: 100-55; SAP: 38.

Balsa; Ochroma lagopus Sw.: 33.

Balsam of Trinidad; Copaifera officinalis L.: 29.

Bálsamo de P. R.; Citharexylum fruticosum L.: 43.

Bamboo, common; Bambusa vulgaris Schrad.: 26.

Ecuadoran Giant; Guadua latifolia (Humb. \& Bonpl.) Kunth (inside): 39.

Tulda; Bambusa tuldoides Munro (inside): 45.

Bambusa tuldoides Munro; Tulda Bamboo (inside): 45.

vulgaris Schrad.; Common Bamboo (inside): 26.

Bamak (U. S. trade); Virola mycetis Pulle: 28

Barakaroeballi of Demerara; Dicorynia guianensis Amsh.: 44.

Barbadian mahogany; Swietenia mahagoni Jacq.: 80; SAP: 58.

Bariaco de P. R.; Krugiodendron ferreum (Vahl) Urban: 83.

Barril de Cuba; Cyrilla racemiflora L.: 45.

Barillo de Panamá; Symphonia globulifera L.f.: 45.

Baromalli of Demerara; Catostemma commune Sandw.: 32.

Basralocus of Demerara; Dicorynia guianensis Amsh: 44.

Bastard Mahogany; Andira inermis (W. Wright) H.B.K. : 46.

Stopper; Petitia domingensis Jacq.: 51.

Bat Seed of Demerara; Andira surinamensis (Bondt.) Splitg.: 77.

Bay Rum Tree; Pimenta racemosa (Mill.) J. W. Moore: 71.

Bayahonda de P. R.; Prosopis juliflora (Sw.) DC.: 50.

Beadtree; Melia azedarach L.: 22.

Bébé of Surinam; Pterocarpus draco L.: 44.

Bebeere of Demerara; Ocotea rodiaei (Schomb.) Mez: 91. 
Becuiba do Brasil; Virola mycetis Pulle: 28.

Beefwood; Casuarina equisetifolia L.: 37.

Beilschmiedia (or Hufelandia) pendula (Sw.) Nees; Guajón de P. R., Aguacate Cimarrón, Cedro Macho, Palo Colorado: 29.

Betula alleghaniensis Britton; Yellow Birch: 26.

Bibiru of Demerara; Ocotea rodiaei (Schomb.) Mez: 91.

Birch, Yellow; Betula alleghaniensis Britton: 26.

West Indian; Bursera simaruba (L.) Sarg.: 23.

Bitter, Old Woman's; Citharexylum fruticosum L.: 43.

Black Cherry; Prunus serotina Ehrh.: 28.

Ironwood; Krugiodendron ferreum (Vahl) Urban: 83.

Kakeralli of Demerara, Eschweilera Sagotiana Miers: 83.

Locust; Robinia pseudoacacia L.: 60.

Mangrove; Avicennia nitida Jacq.: 23.

Olive; Bucida buceras L.: 75; SAP: 56.

Walnut; Juglans nigra L.: 44.

Blakka Pisie of Surinam: Nectandra sp.: 46.

Boarwood; Symphonia globulifera L.: 45.

Boia do Brasil; Sterculia pruriens (Aubl.) Schum.: 32.

Bois Arada d'Haiti; Trichilla pallida Sw.: 84.

Blanc d'Haiti; Phyllosiylon brasiliensis Cap.: 40.

Canelle d'Cayenne; Licaria canella (Meissn.) Kosterm.: 93.

Cochon d'Haiti; Tetragastris balsamifera (Sw.) Kuntze: 45.

Chandelle d'Haiti; Amyris elemifera L.: 100+.

Chêne d'Haiti; Catalpa longissima (Jacq.) Sims: 47; SAP: 45.

Crapaud d'Haiti; Alchornea latifolia Sw.: 21.

d'Arc; Maclura pomifera (Raf.) Schneid.: 92.

d'Fer d'Haiti; Krugiodendron ferreum (Vahl) Urban: 83.

d'Indie Francais; Pimenta racemosa (Mill.) J. W. Moore: 71.

d'Orme d'Haiti; Guazuma ulmifolia Lam.: 33.

d'Ortie d'Haiti; Petitia domingensis Jacq.: 51.

Fourmi d'Cayene; Triplaris surinamensis Cham.: 28.

Gommier d'Cayenne; Protium heplaphyllum March: 59.

Gris-gris d'Haiti; Bucida buceras L.: 75; SAP: 56.

Lait Femelle d'Haiti; Rauwolfia tetraphylla L.: 45.

L'agli of Trinidad; Ryania speciosa Vahl: 100+.

Palmiste d'Haiti; Andira inermis (W. Wright) H.B.K.: 46.

Pin d'Haiti; Pinus occidentalis Sw.: 78.

Soumis d'Haiti; Cordia alliodora (R. \& P.) Oken: 60.

Trompette d'Haiti; Cecropia peltata L.: 28.

Vache d'Haiti; Alchornea latifolia Sw.: 21.

Bolletrie of Surinam; Manilkara bidentata (A. DC.) Chev.: 58. 
Bombacopsis quinatum (Jacq.) Dugand; Pochote de Costa Rica, Cedro Espino de Nicaragua: 44.

Borassus aethiopium Mart.; African Fan Palm: 27.

Bosch Papaya of Surinam; Cecropia peltata L.: 28.

Bosoo of Trinidad, Fagara trinitensis (Williams) J. S. Beard: 74.

Botón, Mangle, Botoncillo, Mangle de P. R.; Conocarpus erectus L.: 45.

Bowdichia nitida Benth.; Sapupira o Sucupira do Brasil, Alcornoque de

Venezuela, Mach of Demerara: 78.

Bowhanti of Surinam; Vouacapoua americana Aubl.: 79.

Boxwood, Brasilian; Euxylophora paraensis Huber: 68.

Brasilian Boxwood or Satinwood; Euxylophora paraensis Huber: 68.

Butternut; Caryocar brasiliense Camb.: 65.

Purpleheart; Pellogyne Lecointei Ducke: 68.

White Pine; Simarouba amara Aubl.: 24.

Breadfruit; Artocarpus altilis (Parkinson) Fosberg: 39; SAP: 25.

Brea-caspi do Brasil; Symphonia globulifera L.f.: 45.

Breu Vermelho do Brasil; Protium heptaphyllum March: 59.

Broomstick; Trichilia hirta L.: 86; SAP: 61.

Brosimum paraense Huber; Muirapiranga do Brasil, Dukaliballi of Demerara, Cardinalwood, Satiné Rubané d'Cayenne: 99.

Brown Silverballi of Demerara; Licaria canella (Meissn.) Kosterm.: 93.

Bruinhart of Surinam; Vouacapoua americana Aubl.: 79.

Buchenavia capitata (Vahl) Eichl.; Granadillo de P. R., Yellow Sanders: 69. Bucida buceras L.; Ucar de P. R., Black Olive, Bois Gris-gris d'Haiti: 75; SAP: 56.

Bulletwood; Manilkara Huberi (Ducke) Standl.: 81, or M. bidentata (A. DC.) Chev.: 58.

Burro de P. R.; Magnolia portoricensis Bello: 52.

Bursera (or Elaphrium) simaruba (L.) Sarg. (= B. gummifera L.); Almácigo de P. R., West Indian Birch, Gumbo-limbo: 23.

Butternut; Juglans cinerea L.: 41.

Brasilian: Caryocar brasiliense Camb.: 65.

Buttontree, Buttonwood; Conocarpus erectus L.: 45.

Byrsonima spicata (Cav.) L. C. Rich.; Maricao de P. R., Serrete of Trinidad: 28.

Cabo de Hacha de P. R.; Trichilia hirta L.: 86; SAP: 61.

Cacao Bobo de R. D.; Melisoma Herberti Rolfe: 38.

Cacao Motillo, C. Roseta, Cacaillo de P. R.; Sloanea berteriana Choisy: 53; SAP: 46.

Cachimbo de P. R., Rauwolfia tetraphylla L.: 45.

Café de P. R.; Coffea arabica L.: 28.

Caimitillo Verde de P. R.; Micropholis garcinifolia Pierre: 37 . 
Cajuil (acepción castiza) de P. R.; Anacardium occidentale L.: 43.

Calaba de Panamá; Calophyllum brasiliense Camb.: 37.

California Redwood; Sequoia sempervirens (D. Don.) Endl.: 54.

Callitris glauca R. Brown; Australian Cypress Pine: 71.

Calophyllum brasiliense Camb., var. antillanum (Britton) Standl.; María

de P. R., Palo de María, Santa María, Dame Marie d'Haiti, Dam-

age: 37 .

lucidum Benth.; Galba of Trinidad: 39.

Calycogonium squamulosum Cogn.; Camacey Jusillo de P. R., Granadilla

Cimarrona: 35.

Calypthranthes concinna DC.; Camboim Branco do Brasil: 32.

Camacey Jusillo de P. R.; Calycogonium squamulosum Cogn.: 35.

Camboim Branco do Brasil; Calypthranthes concinna DC.: 32.

Camboim Sinho do Brasil; Myrciaria delicatula (DC.) Bg.: 40.

Camphorwood from Formosa; Cinnamomum Camphora (L.) Sieb.: 100.

Candlewood; Dacryodes excelsa Vahl: 31.

Canela do Folha Rodanda do Brasil; Cryptocarya Mandiocanna Meiss.: 46.

Canela Guaicá do Brasil; Ocotea arechavaletae Mez: 27.

Canela Preta do Brasil; Nectandra saligna Nees: 22.

Cañón Oak, Quercus chrysolepis Liebm.: 24.

Caoba de R.D. y P.R.; Swietenia mahagoni Jacq.: 80, SAP: 58.

de Méjico o Caoba Hondureña; Swietenia macrophylla King: 59; SAP: 50.

Caobanillo de R. D., Caobana, Caobillo; Stahlia monosperma (Tul.) Urban: 73.

Caopiá do Brasil; Vismia macrophylla H.B.K.: 34.

Caoutchouc d'Haiti; Ficus elastica Nois.: 28.

Capá de P. R., Capá Prieto; Cordia alliodora (R. \& P.) Oken: 60.

Capá Blanco de P. R., C. Sabana, C. Sabanero; Petitia domingensis Jacq.: 51.

Caracolí de R. D.; Lysiloma latisiliqua (L.) Benth.: 72.

Caracolillo de P. R.; Homalium racemosum Jacq.: 71.

Caracolillo de R. D.; Trichilia pallida Sw.: 84.

Carapa guianensis Aubl. (= C. procera De.); Crappo of Trinidad, Crabwood, Krappa of Surinam, Andiroba do Brasil: 36.

nicaraguensis C. DC.; Cedro Macho de Nicaragua: 36.

Cardinalwood; Brosimum paraense Huber: 99.

Carimbo of Trinidad; Guarea glabra Vahl: 63.

Cariniata pyriformis Miers; Albarco de Colombia, Bacú de Venezuela: 60.

Caroba do Brasil; Jacaranda semiserrata Cham.: 27.

Carya glabra (Mill.) Sweet; Pignut hickory: 31.

Caryocar brasiliense Camb. (= C. villosum); Piquiá do Brasil, Brasilian

Butternut: 65. 
Casha de P. R., Cashia of Bahamas; Acacia farnesiana (L.) Willd.: 72.

Cashew, Cashew Nut Tree; Anacardium occidentale L.: 43.

Casia Amarilla de P. R.; Cassia siamea Lam.: 33.

Cassia siamea Lam.; Casia Amarilla de P. R.: 33.

Castanha Sapucaia do Brasil; Lecythis paraensis (Huber) Ducke: 75.

Casuarina equisetifolia L.; Australian Pine, Pino Australiano de P. R., Pin d'Australie, Beefwood: 37.

Catalpa longissima (Jacq.) Sims; Haitian Oak, Chêne Haitien, Bois Chêne d'Haiti, Roble de la R. D.: 47, SAP: 45.

Catostemma commune Sandw.; Baromalli or Adaurona of Demerara, Flambeau Rouge d'Cayenne: 32 .

Cayepon d'Haiti; Linociera domingensis (Lam.) Knobl.: 46.

Cecropia peltata L.; Yagrumo Hembra de P. R., Bosch Papaya of Surinam, Ambaiba do Brasil, Bois Trompette d'Haiti: 28.

Cedar, Red; Juniperus virginiana L.: 49.

Yellow; Chamaecyparis nootkatensis (D. Don) Spach: 55.

West Indian or Spanish; Cedrela odorata L.: 61 .

Western Red; Thuja plicata Donn: 44.

White; Tabebuia pallida Miers: 34 .

Cedrela fissilis Vall.; Cedro do Brasil: 39. odorata L.; Cedro de P. R., West Indian or Spanish Cedar: 61. toona Roxb.; Cedro toona (grown in P. R.): 51.

Cedro de P. R.; Cedrela odorata L.: 61.

do Brasil; Cedrela fissilis Vall.: 39.

Hembra; Turpinia paniculata Vent.: 73.

Espino de Nicaragua; Bombacopsis quinatum (Jacq.) Dugand: 44.

Macho; Hyeronima clusioides (Tul.) Muell. Arg.: 47. or Beilschmiedia pendula (Sw.) Nees: 29.

Macho de Nicaragua; Carapa nicaraguensis C. DC.: 43.

Prieto de P. R.; Metopium toxiferum (L.) Krug et Urban: 26.

Rana do Brasil; Vochysia maxima Ducke: 44.

Toona; Cedrela toona Roxb.: 51.

Cedrohy do Brasil; Tapirira marchandii Engl.: 24.

Ceiba pentandra (L.) Gaertn.; Ceiba de P. R., Mapou d'Haiti: 25.

Cenicero de America Central; Pithecellobium saman (Jacq.) Benth.: 57.

Cenizo o Cenizo Rubial de P. R.; Zanthoxylum martinicense (Lam.) DC.: 27.

Central American or Mexican Walnut; Enterolobium cyclocarpum (Jacq.) Gris.: 67.

Cer6n de Mexico; Phyllostylon brasiliensis Cap.: 39.

Chamaecyparis formosensis Matsum.: 49 (no longer toxic after 1-year exposure to the air). 
nootkatensis (D. Don) Spach; Yellow Cedar: 55.

obtusa Sieb \& Succ.: 67 (no longer toxic after 1-year exposure to the air). Chêne Callebassie d'Haiti; Petitia domingensis Jacq.: 51.

Caparo d'Haiti; Cordia alliodora (R. \& P.) Oken: 60.

Haitien; Catalpa longissima (Jacq.) Sims: 47, SAP: 45.

Chewstick of British Honduras; Symphonia globulifera L.: 45.

Chifle de Vaca de P. R.; Avicenia nitida Jacq.: 23.

China de P. R.; Citrus sinensis Osbeck: 27.

Chinaberry; Melia azedarach L.: 22.

Cherry, Wild Black; Prunus serotina Ehrh.: 28.

Chlorophora excelsa Benth. \& Hook f.; Iroko of Africa: 90.

tinctoria (L.) Gaud.; Mora de P. R., Amoeira Brava do Brasil, Dyer's

Mulberry: 88. Fustic of Trinidad: 65 (possibly SAP).

Chloroxylon swietenia DC.; Indian Satinwood from Africa: 95.

Cieza de Venezuela; Ryania speciosa Vahl; still toxic after 5 years: $100+$.

Cinnamomum Camphora (L.) Sieb.; Camphorwood of Formosa: 100.

micranthum Hay: 47.

Citharexylum fruticosum L.; Pendula de P. R., Balsamo, Palo de Guitarra

de Cuba, Fiddlewood, Old Woman's Bitter: 43.

Citrus sinensis Osbeck; China de P. R., Orange: 27.

Clusea rosea Jacq.; Cupey de P. R., Pitch Apple, Wild Mammee, Figuier

d'Haiti, Strangling Fig, Scotch Lawyer of Trinidad: 27.

Cóbana de P. R., C. Negra, Cóbano; Stahlia monosperma (Tul.) Urban: 73. Cocaina Falsa; Erythroxylon aerolatum L.: 81.

Coccoloba (or Coccolobis) grandifolia Jacq.; Moralón: 66.

rugosa Desf.; Ortegón: 72.

uvifera (L.) L.; Uvero de P. R., Uva de Mar. Seagrape, Raisin la Mer d'Haiti: 30.

Cocorrón, Coscorrón de P. R.; Elaeodendron xylocarpum (Vent.) DC.: 35.

Coffea arabica L.; Café de P. R.; Coffee: 28.

Conacaste de America Central, and U. S. Trade; Enterolobium cyclocarpum

(Jacq.) Gris.: 67.

Conocarpus erectus L.; Mangle Botón de P. R.; M. Botoncillo, Buttonwood,

Buttontree, Palétuvier d'Haiti: 45.

Copaiba de R. D.; Copaifera officinalis L.: 29.

Copaifera officinalis L.; Copaiba de R. D., Balsam of Trinidad: 29.

Cordia alliodora (Ruiz \& Pav.) Cham.; Capá de P. R., Capá Prieto, Spanish

Elm, Princewood, Cypre of Trinidad, Bois Soumis d'Haiti, Chêne

Caparo d'Haiti: 60.

Goeldiana Huber; Freijo do Brasil, Jennywood: 51.

hypoleuca DC.; Louro do Río Grande do Sul do Brasil: 22.

Corona do Brasil; Acacia farnesiana (L.) Willd.: 72. 
Corkwood; Ochroma lagopus Sw.: 33.

Coton Fleurs d'Haiti; Ochroma lagopus Sw.: 33.

Courbaril; Hymenaea courbaril L.: 89.

Cow Tamarind of Trinidad; Pithecellobium saman (Jacq.) Benth.: 57.

Crabwood, Crappo; Carapa guianensis Aubl.: 36.

Cryptocarya Mandioccana Meiss.; Canela do Folha Redonda do Brasil: 46.

Cypre of Trinidad; Cordia alliodora (Ruiz \& Pav.) Cham.: 60.

Cypress, Southern or Bald; Taxodium distichum (L.) Rich.; very gummy, fine-grained: 100; gummy: 79; fine-grained, not gummy: 55; SAP: 38.

Pine, Australian; Callitris glauca R. Brown: initially very repellent: 100+; after 5-year exposure: 71.

Cyrilla racemiflora L.; Palo Colorado de P. R., Barril de Cuba, Leatherwood of U.S.A.: 45.

Cunninghamia sinensis R. Brown, from Formosa: 48 (after 1-year exposure to air).

Cucubano de P. R.; Guettarda laevis Urban: 29.

Cujani de Cuba; Prunus occidentalis Sw.: 84.

Cupania americana L.; Guara de P. R.: 23.

Cupey de P. R.; Clusea rosea Jacq.: 27.

Cupiuba do Brasil; Goupia glabra Aubl.: 77.

Dacryodes excelsa Vahl; Tabonuco de P. R., Candlewood: 29.

Dame Marie d'Haiti, Damage; Calophyllum brasiliense Camb., var. antillanum (Britton) Standl.: 37.

Delonix (or Poinciana) regia (Bojer) Raf.; Flamboyán de P. R., Flamboyant d'Haiti, Flametree, Royal Poinciana: 20.

Demerara Greenheart; Ocotea rodiaei (Schomb.) Mez: 91.

Determa of Demerara; Octoea rubra Mez: 57.

Dicorynia guianensis Amsh.; Basrolocus and Barakaroeballi of Demerara, Angélique d'Cayenne, Angelica do Pará, Tapaiuna do Brasil: 44.

Didymopanax morototoni (Aubl.) Dene. et Pl.; Grayumo o Yagrumo Macho de P. R.: 27.

Diplotropis purpurea (Rich.) Amsh.; Tatabu of Demerara: 76.

Distemonanthus benthamianus Baill., from Africa: 64.

Djedoe of Surinam; Sclerolobium melinonii Harms: 44.

Doctor Gum; Symphonia globulifera L.f.: 45.

Dombou d'Haiti; Trichilia pallida Sw.: 84.

Dominican Mahogany; Swietenia mahagoni Jacq.: 80.

Doncella; Matayba domingensis (DC.) Radlk.: 27.

Douglas Fir, Douglas Spruce; Pseudotsuga menziesii (Mirb.) Franco: 55;

SAP: 49. 
Duka of Demerara; Tapirira marchandii Engl.: 24.

Dukaliballi of Demerara; Brosium paraense Huber: 99.

Dutch Mahogany; Virola mycetis Pulle: 28.

Dyer's Mulberry; Chlorophora tinctoria (L.) Gaud.: 88.

East Indian Teak; Tectona grandis L.f.: 80.

Ebonywood; Krugiodendron ferreum (Vahl) Urban: 83.

Ecuadoran Giant Bamboo; Guadua latifolia (Humb. \& Bonpl.) Kunth (inside): 39 .

Elaeodendron xylocarpum (Vent.) DC.; Cocorrón o Coscorrón de P. R., Guayarote, Nut Muscat, Marbletree: 35.

Elm, Spanish; Cordia alliodora (R. \& P.) Oken: 60.

West Indian; Guazuma ulmifolia Lam.: 33.

Enterolobium cyclocarpum (Jacq.) Gris.; Guanacaste o Conacaste de America Central (and U.S. Trade), Central American Walnut: 67. Eperua falcata Aubl.; Soft Wallaba of Demerara: 56.

Erythroxylon areolatum L.; Sapo Blanco de P. R., Aroba o Arobillo de Cuba y R. D., Poirier d'Haiti, Indio, Cocaina Falsa, False Concaine: 81 .

Eschweilera corrugata (Poit.) Miers; Wena Kakeralli of Demerara: 47.

Sagotiana Miers; Black Kakeralli of Demerara: 83.

Espavé o Espavél de Panamá; Anacardium excelsum (B. \& B.) Skeels: 68. Espejuelo de P. R.; Krugiodendron ferreum (Vahl) Urban: 83.

Espinillo de R. D.; Zanthoxylum flavum (Vahl): 72.

Espino Rubial; Zanthoxylum martinicense (Lam.) DC: 27.

Eucalyptus citriodora Hook (grown in P. R.) : 27.

micrococera F. Muell. (from New South Wales and Queensland): 57. robusta Smith (grown in P. R.): 30.

Eugenia jambos L.; Pomarrosa de P. R., Pomme Rose d'Haitii, Rose Apple, Malabar Plum: 22.

Stahlii (Kiaersk.) Krug et Urban; Guayabota o Limoncillo de P. R.: 33. Euxylophora paraensis Huber; Pau Amarello do Brasil, Brasilian Boxwood, B. Satinwood: 68 .

Fagara (or Zanthoxylum) flavum Vahl.; Aceitillo de Cuba y P. R., Espinillo de R. D., Yellow Sanders of Florida, Satinwood of British West Indies: 72.

macrophylla (Oliv.) Engler, from Africa: 85 .

trinitensis (Williams) J. S. Beard; Bosoo of Trinidad: 74.

False Cocaine; Erythroxylum areolatum L.: 81.

Fan Palm, African; Borassus aethiopium Mart.: 27.

Ficus elastica Nois.; Palo de Goma de P. R., Caoutchouc d'Haiti, Rubber Tree: 28. 
laevigata Vahl.; Jagüey de P. R.: 26.

pumila L.; Yedra de P. R.; 29.

retusa $\mathrm{L}$. (= nitida Thunb.); Laurel de la India de P. R.: 31; SAP: 21.

Fiddlewood; Petitia domingensis Jacq.: 51 or Vitex divaricata Sw.: 42.

Figuier Maudit Marron d'Haiti; Clusia rosea Jacq.: 27.

Fir, Douglas; Pseudotsuga menziesii (Mirb.) Franco: 55; SAP: 49.

Flambeau Rouge d'Cayenne; Catostemma commune Sandw.: 32.

Flamboyán de P. R., Flamboyánt d'Haiti, Flametree; Delonix regia (Bojer)

Raf.: 20.

Formigueira d'Cayenne; Triplaris surinamensis Cham.: 28.

Fraxinums americana L.; White Ash (grown in P. R.): 27.

Freijo do Brasil; Cordia Goeldiana Huber: 51.

Fuma Brava do Brasil; Solanum auriculatum Ait.: 20.

Fustic of Trinidad; Chlorophora tinctoria (L.) Gaud.: 65 (possibly SAP).

Gaeta d P. R.; Trichilia pallida Sw.: 84.

Gaïac d'Haiti, G. Franc, G. Male; Guaiacum officinale L.: 100; SAP: 58.

Galba of Trinidad, Calophyllum lucidum Benth.: 39.

Gale Silverballi of Demerara; Aniba ovalifolia Mez: 94.

Genipa americana L.; Jagua de P. R., Genipaporana do Brasil, Gene-pas ou Genipayer d'Haiti: 34.

Genipaporana do Brasil, Gene-pas ou Genipayer d'Haiti; Genipa americana L.: 34 .

Genícero de Costa Rica, Genizero and Jenisero (U.S. Trade); Enterolobium cyclocarpum (Jacq.) Gris.: 67.

Geo-geo de P. R., Laurel; Ocotea leucoxylon (Sw.) Maza: 48.

Gipio do Brasil; Pithecellobium saman (Jacq.) Benth.: 57.

Gommier Rouge d'Cayenne; Tetragastris Hostmannii (Engl.) Kuntze: 56.

Gossweilerodendron balsamiferum Harms, from Africa: 69.

Goupia glabra Aubl.; Kabukalli of Demerara, Cupiuba do Brasil: 77.

Gouyave d'Haiti; Psidium guajava L.: 32; SAP: 23.

Granadilla Cimarrona; Calycogonium squamulosum Cogn.: 35.

Granadillo de P. R.; Buchenavia capitata (Vahl) Eichl.: 68.

Grayumo Macho de P. R.; Didymopanax morototoni (Aubl.) Dene. et Pl.:

27.

Greenheart, Demerara; Ocotea rodiaei (Schomb.) Mez: 91.

Hakia; Tabebuia capitata (Bur. \& K. Schum.) Sandw.: 95.

Gregory; Bucida buceras L.: 75; SAP: 56.

Grevillea robusta Cunn.; Silver Oak, Australian Oak: 21.

Grignon d'Cayenne; Ocotea rubra Mez: 57.

Gronfoloe of Surinam; Qualea albiflora Warm.: 42.

Guaba de P. R.; Inga vera Willd.: 28.

Guácima de P. R.; Guazuma ulmifolia Lam.: 33. 
Guadua latifolia (Humb. \& Bonpl.) Kunth; Ecuadoran Giant Bamboo (inside): 39.

Guaiacum officinale L.; Guayacán de P. R., Lignum-vitae, Gaïac d'Haiti, G. Franc, G. Male: 100; SAP: 58.

Guaita de P. R.; Trichilia hirta L.: 86; SAP: 61.

Guajón de P. R., Beilschmiedia pendula (Sw.) Nees: 29.

Guamá de P. R.; Inga laurina (Sw.) Willd.: 28.

Guanacaste de America Central (and U. S. Trade); Enterolobium cyclocarpum (Jacq.) Gris.: 67.

Guango de Panamá; Pithecellobium saman (Jacq.) Benth.: 57.

Guano de P. R.; Ochroma lagopus Sw.: 33.

Guara de P. R.; Cupania americana L.: 23.

Guaraguao de P. R.; Guarea trichiliodes L.: 70.

Guarea glabra Vahl; Carimbo of Trinidad: 56. guara (Jacq.) P. Wilson; Redwood of Trinidad: 48.

trichilioides L.; Guaraguao de P. R., Alligatorwood: 70.

Guarikama de Venezuela; Ryania speciosa Vahl: still toxic after 5-year exposure: $100+$.

Guatacare of Trinidad; Lecythis paraensis (Huber) Ducke: 75.

Guava; Psidium guajava L.: 32; SAP: 23.

Guayabón de Panamá; Terminalia amazonia (Gmel.) Exel.: 70.

Guayabota de P. R.; Eugenia Stahlii (Kiaersk.) Krug et Urban: 33.

Guayacán de P. R.; Guaiacum officinale L.: 100; SAP: 58.

Guayarote de P. R., Elaeodendron xylocarpum (Vent.) DC.: 35.

Guayavacón; Trichilia hirta L.: 86; SAP: 61.

Guazuma ulmifolia Lam.; Guácima de P. R., W.I. Elm, Bois d'Orme d'Haiti: 33.

Guettarda laevis Urban; Cucubano de P. R.: 29.

Gumbo-limbo; Bursera simaruba (L.) Sarg.: 23.

Gumwood; Liquidambar styraciflua L.: 29.

Haa or Hame of Hawaii; Antidesma platyphyllum Mann.: 61.

Hachiballi of Demerara; Simaba multiflora Juss.: 23.

Haiowaballi of Demerara; Tetragastris Hostmannii (Engl.) Kuntze: 56.

Haitian Oak; Catalpa longissima (Jacq.) Sims: 47; SAP: 45.

Hakia Greenheart of Demerara; Tabebuia capitata (Bur \& K. Schum.) Sandw.: 95.

Harde Pisie of Surinam; Nectandra sp.: 46.

Hariraru; Ocotea canaliculata (Rich.) Mez: 57.

Hawaiian Koa; Acacia koa Asa Gray, var. hawaiiensis: 48.

Hemlock; Tsuga canadensis (L.) Carr.: 38.

Hernandia sonora L.; Mago de P. R., Jack-in-the-box of Barbados, Toporite of Trinidad: 26. 
Hibiscus tiliaceus L.; Mahoe of Jamaica (grown in P. R.): 45; SAP: 44. Hickory, Pignut; Carya glabra (Mill.) Sweet: 31.

Hieronyma, see Hyeronima.

Higüerillo de P. R.; Vitex divaricata Sw.: 42.

Hincha-huevos de P. R.; Sapium laurocerasus Desf.: 24.

Hippomane mancinella L.; Manzanillo de P. R., Manchineel, Mancinillier ou Pomme Zombi d'Haitii: 31.

Hog Plum; Spondias mombin L.: 24.

Holly; Ilex opaca Art.: 28.

Homalium racemosum Jacq.; Caracolillo de P. R., Tostado: 71.

Hooglandmataki of Surinam; Symphonia globulifera L.f.: 45.

Honduras Mahogany; Swietenia macrophylla King: 59; SAP: 50.

Hububalli of Demerara; Loxopterygium Sagotti Hook f.: 57.

Hueso Blanco de P. R.; Linociera domingensis (Lam.) Knobl.: 46.

Prieto de P. R.; Ilex nitida (Vahl.) Maxim: 35.

Huisache de Méjico; Acacia farnesiana (L.) Willd.: 72.

Humboldt's Willow; Salix Humbolditana Willd.: 20. .

Humiria balsamifera Aubl.; Umiri do Brasil, Tauroniro of Surinam: 63.

Hura crepitans L.; Javillo de P. R., Sand-Box, Monkey-Pistol, Sablier d'Haiti, Possentrie of Surinam: 28.

Hyeronima caribaea Urban; Tapana of Trinidad: 44.

clusioides (Tul.) Muell. Arg.; Cedro Macho de P. R.: 47.

laxiflora Muell. Arg.; Suradan of Demerara: 47.

Hymenaea courbaril L.; Algarrobo de P. R., W. I. Locust: 89.

Ilex nitida (Vahl.) Maxim; Hueso Prieto de P. R.; 35.

opaca Art.; Holly: 28.

Indian Almond; Terminalia catappa L.: 32 .

Satinwood (from Africa); Chloroxylum swietenia DC.: 95.

Indio de P. R.; Erythroxylon areolatum L.: 81.

Inga laurina (Sw.) Willd.; Guamá de P. R.: 28.

Inga vera Willd.; Guaba de P. R., Sucrin ou Poix Doux d'Haiti, Inga: 28.

Intsia bijuga (Coteber.) Kuntze; Ipil (Australia): 88.

Ipe Roxo do Brasil; Tabebuia ipe (Mart.) Standl.: 22.

Ipil; Intsia bijuga (Coteber.) Kuntze: 88.

Iroko of Africa; Chlorophora excelsa Benth. \& Hook f.: 90.

Ironwood, Black; Krugiodendron ferreum (Vahl) Urban: 83.

Itaúba do Brasil; Mezilaurus (Silvia) itauba (Meissn.) Taub.: 59.

Iteballi of Demerara; Vochysia tetraphylla (G.F.W. Mey.) DC.: 56.

Ivy, Poison; Toxicodendron radicans (L.) Kuntze, SAP: 35.

Jácana de P. R.; Pouteria multiflora A. DC.: 46.

Jacaranda semiserrata Cham.; Caroba do Brasil: 27.

Jack-in-the-box; Hernandia sonora L.; 26. 
Jagua de P. R.; Genipa americana L.: 34 .

Jagüey de P. R.; Ficus laevigata Vahl.: 26.

Jatía de Cuba; Phyllostylon brasiliensis Cap.: 40.

Javillo de P. R.; Hura crepitans L.: 28.

Jennywood of Brasil; Cordia Goeldiana Huber: 51.

Jigue de Cuba; Lysiloma latisiliqua (L.) Benth.: 72.

Jobillo de P. R.; Trichilia hirta L.: 86; SAP: 61.

Jobo de P. R.; Spondias mombin L.: 24.

Jovillo de P. R.; Hura crepitans L.: 28.

Juglans cinerea L.; Butternut: 41.

nigra L.; Black Walnut: 44.

Juniperus gracilior Pilger; Sabina de R. D.: 52.

virginiana L.; Cedar, Red Cedar, Pencil Cedar, Juniper: 49.

Kabukalli of Demerara; Goupia glabra Aubl.: 77.

Kakeralli, Black, of Demerara; Eschweilera Sagotiana Miers: 83.

Wena, of Demerara; Eschweilera corrugata (Poit.) Miers: 47.

Kaneelhart of Surinam; Licaria canella (Meissn.) Kosterm.: 93.

Keriti of Demerara; Ocotea wachenheimii R. Ben.: 48.

Khaya ivorensis Chev.; African Mahogany: 30.

Koa of Hawaii; Acacia koa Asa Gray, var. hawaiiensis: 48.

Kooel Pialli d'Cayenne; Loxopterygium Sagotti Hook f.: 57.

Krappa of Surinam; Carapa guianensis Aubl.: 36.

Krugiodendron ferreum (Vahl) Urban; Palo de Hierro de P. R., Black

Ironwood of Florida and Jamaica, Bois de Fer d'Haiti, Bariacoa de

P. R., Espejuelo de P. R., Quiebra Hacha de Méjico, Ebonywood: 83.

Kuraru of Demerara; Andira surinamensis (Bondt.) Splitg.: 77.

Kuroburelli of Demerara and Surinam; Peltogyne pubescens Benth.: 72.

Kurokai of Demerara; Protium decandrum March: 32.

Kwalie, Wirsiwirsi of Surinam; Qualea dinizii Ducke: 56.

Lanan, Red; Shorea negrosensis Foxw.: 33.

Lancewood, Red; Manilkara Huberi (Ducke) Standl.: 81.

Larch; Larix occidentalis Nutt.: 38.

Larenjeira do Mato do Brasil; Actinostemon concolor (Spreng.) Muell. Arg.: 35.

Larix occidentalis Nutt.; Larch: 38.

Laugeria resinosa Vahl.; Aquilón de P. R.: 52.

Laurel Amarillo; Nectandra Sintenisii Mez: 27.

Avispillo; Nectandra coriaceae (Sw.) Griesb.: 35.

de la India; Ficus retusa L. (=F. nitida Thunb.): 31; SAP: 21.

Geo-geo de P. R.; Ocotea leucoxylon (Sw.) Maza: 48.

Sabino de P. R.; Magnolia splendens Urban: 40. 
Leche Prieto de P. R.; Micropholis chrysophylloides Pierre: 48.

Lecherillo de P. R.; Sapium laurocerasus Desf.: 25.

Leatherwood; Cyrilla racemiflora L.: 45.

Lecythis paraensis (Huber) Ducke; Sapucaia do Brasil, Castanha Sapucaia, Monkey-Pot, Guatacare of Trinidad: 75.

Letterwood of Demerara; Piratinera guianensis Aubl.: 96.

Licania densiflora Kleinh.; Marishiballi of Demerara: 62.

Licaria canella (Meissn.) Kosterm.; Brown Silverballi of Demerara, Kaneelhart of Surinam, Bois Canelle d'Cayenne; Wabaima of Demerara: 93.

Lignum-vitae; Guaiacum officinale L.: 100; SAP: 58.

Lilas, Lilaila de P. R.; Melia azedarach L.: 22.

Limoncillo de P. R.; Pimenta racemosa (Mill.) J. W. Moore: 71, or Eugenia Stahlii (Kiaersk.) Krug et Urban: 33.

Linociera (or Mayepea) domingensis (Lam.) Knobl.; Hueso Blanco de P. R., Tarana de R.D., Cayepon d'Haiti, Wild Cocoplum: 46.

Liquidambar styraciflua L.; Redgum, Gumwood: 29.

Liriodendron tulipifera L.; Yellow Poplar, Tulip Tree: 41.

Lithraea brasiliensis March; Aroeira Bugra do Brasil: 40.

Lizardwood; Vitex divaricata Sw.: 42.

Llagrumo de P. R.; Cecropia peltata L.: 28.

Loblolly Pine; Pinus taeda L.: 22士.

Locust, Black; Robinia pseudoacacia L.: 60.

West Indian; Hymenaea courbaril L.: 89.

Louro Abacate do Brasil; Pleurothyrium cuneifolium Nees: 56.

do Brasil; Cordia hypoleuca DC.: 22.

Tamancao do Brasil; Ocotea acutangula Mez: 64.

Vermelho do Brasil; Ocotea rubra Mez: 57.

Loxopterygium Sagotii Hook f.; Hububalli of Demerara, Slangenhout of Surinam, Kooel Pialli d'Cayenne, Onotillo de Venezuela: 57.

(Lucuma) Pouteria multiflora A. DC.; Jácana o Acana de P. R.: 46.

Luehea divaricata Mart.; Acoita-Cavalo do Brasil: 28.

Lysiloma latisiliqua (L.) Benth.; Caracoli de R. D., Tavernon d'Haiti, Sabicú o Jigue de Cuba: 72.

Macacahuba do Brasil; Platymiscium Ulei Harms: 98.

Mach of Demerara; Bowdichia nitida Benth.: 78.

Maclura (or Toxylon) pomifera (Raf.) Schneid.; Osage Orange, Mock Orange, Bois d'Arc: 92.

Magnolia portoricensis Bello; Mauricio de P. R., Burro: 52.

splendens Urban; Laurel Sabino de P. R., Sabino: 40.

Maga de P. R.; Montezuma speciosissima Sessé \& Moc.: 87.

Mago de P. R.; Hernandia sonora L.; 26. 
Maháudéme d'Haiti; Ochroma lagopus Sw.: 33.

Mahban (U.S. Trade); Virola mycetis Pulle: 31.

Maho or Manmaho of Demerara, Mahot Cochon d'Cayenne; Sterculia pruriens (Aubl.) Schum.: 32.

Mahoe of Trinidad; Sterculia caribaea R. Br.: 26.

Mahoe of Jamaica (grown in P. R.); Hibiscus tiliaceus L.: 45; SAP: 44.

Mahogany, African; Khaya ivorensis Chev.: 30.

Barbadian or Dominican; Swietenia mahagoni Jacq.: 80; SAP: 58.

Dutch (P. R. Trade); Virola mycetis Pulle: 28.

Honduras; Swietenia macrophylla King: 59; SAP: 50.

Philippine; Shorea negrosensis Foxw.: 33.

West Indian; Swietenia mahagoni Jacq.: 80; SAP: 58.

Malabar Almond; Terminalia catappa L.: 32.

Plum; Eugenia jambos L.: 22.

Malagueta de P. R.; Pimenta racemosa (Mill.) J. W. Moore: 71.

Mamani of Hawaii; Sophora chrysophylla (Salisbury) Seemann: 52.

Mamey de P. R., Mammee, M. Apple; Mammea americana L.: 30.

Mammea americana L.; Mamey de P. R., Mammee, M. Apple, Abricotier d'Haiti, Abricotiero: 30.

Manchineel, Mancinillier d'Haiti, Manzanillo de P. R.; Hippomane mancinella L.: 31.

Mancinillier d'Haiti; Metopium toxiferum (L.) Krug et Urban: 26.

Mandioquiera do Brasil, Qualea albiflora Warm.: 42.

Mangle Bobo de P. R., M. Negro, M. Prieto, Manglier Noir d'Haiti; Avicennia nitida Jacq.: 23.

Botón de P. R., M. Botoncillo; Concarpus erectus L.: 45.

Colorado de P. R., Manglier Rouge d'Haiti; Rhizophora mangle L.: 50; SAP: 41.

Mangifera indica L.; Mango de P. R., Manguier d'Haiti: 48.

Maní d'Cayenne; Symphonia globulifera L.f.: 45.

Manilkara (or Mimusops) Huberi (Ducke) Standl.; Massaranduba do Brasil, Balata, Red Lancewood, Bulletwood: 81.

bidentata (A. DC.) Chev.; Ausubo de P. R., Bulletwood, Sapotille ( $=M$. nitida (Sessé \& Moc.) Dubard; Bolletrie of Surinam: 58. The reaction of the termites, finding no difference in palatability between the Bolletrie of Dutch Guiana and the Ausubo of Puerto Rico, is in complete agreement with the opinion of the systematists as to their specific identity.)

Manniballi of Demerara; Symphonia globulifera L.f.: 45.

Maple; Acer rubrum L.: 26.

Mapou d'Haiti; Ceiba pentandra (L.) Gaertn.: 25.

Marañón de Ecuador; Anacardium sp.: 44. 
Marbletree; Elaeodendron xylocarpum (Vent.) DC.: 35.

María de P. R.; Calophyllum brasitiense Camb. var. antillanum (Britton) Standl.: 37.

Maricao de P. R.; Byrsonima spicata (Cav.) L. C. Rich.: 28.

Marie-Jeanne d'Haiti; Trichilia pallida Sw.: 84.

Marishiballi of Demerara, Licania densiflora Kleinh.: 62.

Marupá do Brasil; Simarouba amara Aubl.: 24.

Masa de P. R., Masa Colorado; Tetragastris balsamifera (Sw.) Kuntze: 45.

Massaranduba do Brasil; Manilkara Huberi (Ducke) Standl.: 81.

Mataki of Surinam; Symphonia globulifera L.f.: 45.

Matayba domingensis (DC.) Radlk.; Negra Lora de P.R., Doncella, Téa Cimarrona, Ratón: 27.

Mauricio de P. R., Magnolia portoricensis Bello: 52.

(Mayepea) Linociera domingensis (Lam.) Knobl.; Hueso Blanco de P. R., Taranta de R. D., Cayepon d'Haiti, Cocoplum: 46.

Melia azedarach L.; Pasilla o Lilaila de P. R., Lilas d'Haiti, Chinaberry, Beadtree: 22 .

Melisoma Herberti Rolfe; Aguacatillo de P. R., Cacao Bobo de R. D.: 38.

Melón de Nicaragua; Phyllostylon brasiliensis Cap.: 40.

Mesquite; Prosopis juliflora (Sw.) DC.: 50.

Metrosideros polymorpha (Gaud.) Rock; Ohia Lehua from Hawaii: 52.

Metopium toxiferum (L.) Krug et Urban; Papayo de Mona, Cedro Prieto de P. R., Mancinillier d'Haiti, Poisonwood: 26.

Mexican Walnut; Enterolobium cyclocarpum (Jacq.) Gris.: 67.

Mezilaurus (= Silvia Duckei A. Samp.) itauba (Meissn.) Taub.; Itauba do Brasil, Tapinhoam of Surinam: 59.

garcinifolia Pierre; Caimitillo Verde de P. R.: 37.

Micropholis chrysophylloides Pierre; Leche Prieto de P. R.: 48.

Mierenhout, Mirahoedoe of Surinam; Triplaris surinamensis Cham.: 28.

Milkbush; Rauwolfia tetraphylla L.: 45.

(Mimusops) Manilkara Huberi (Ducke) Standl.: 81.

Manilkara bidentata ( $=M$. nitida Sessé \& Moc. Dubard) (A. DC.) Chev.: 58.

Moca de P. R.; Andira inermis (W. Wright) H.B.K.: 46.

Mock Orange; Maclura pomifera (Raf.) Schneid.: 92.

Molinillo de P. R., Mombin Batard d'Haiti; Trichilia hirta L.: 86; SAP: 61.

Mombin Franc d'Haiti; Spondias mombin L.: 24.

Monkey-Pistol, Molinillo de P. R.; Hura crepitans L.: 28.

Monkey-Pot; Lecythis paraensis (Huber) Ducke: 75.

Montezuma speciosissima Sessé \& Moc.; Maga de P. R.: 87.

Mora de P. R.; Chlorophora tinctoria (L.) Gaud.: 88.

Mora of Trinidad, Mora excelsa Benth.: 49. 
Mora excelsa Benth.; Mora of Trinidad: 49.

Gonggrijpii (Kleinh.) Sandw.; Morabukea of Demerara: 82.

Morabukea of Demerara; Mora Gonggrijpii (Kleinh.) Sandw.: 82.

Moralón de P. R., Coccoloba grandifolia Jacq.: 66.

Morus rubra L.; Mulberry: 27.

Motillo, Cacao, de P. R.; Sloanea berteriana Choisy: 53.

Muirapinima Preta do Brasil; Zollneria paraensis Huber: 97.

Muirapiranga do Brasil; Brosimum paraense Huber: 99.

Mulberry; Morus rubra L.: 27.

Muscat, Nut; Elaeodendron xylocarpum (Vent.) DC.: 35.

Muskwood; Guarea trichilioides L.: 70.

Myrciaria delicatula (DC.) Bg.; Camboim Sinho do Brasil: 40 .

Naranja de Cuba; Citrus sinensis Osbeck: 27.

Nectandra coriaceae (Sw.) Griesb.; Laurel Avispillo de P.R.: 35.

Nectandra curia saligna Nees; Canela Preta do Brasil: 22.

Sintenisii Mez; Laurel Amarillo de P. R.: 27.

sp.; Harde Pisie of Surinam, Blakka Pisie, Keretiballi of Demerara: 46. sp.; "Wane" of Surinam (not Ocotea rubra): 90.

Negra Lora; Matayba domingensis (DC.) Radlk.: 27.

Nemocá de P. R.; Ocotea moschata (Meissn.) Mez: 36 or Ocotea spathulata Mez: 29.

Northern White Pine; Pinus strobus L.: $55 \pm$.

Nuez Cimarrona de P. R., del Pais, y Moscado de P. R.; Ocotea moschata (Meissn.) Mez: 36.

Nut Muscat; Elaeodendron xylocarpum (Vent.) DC.: 35.

Oak, Australian Silver; Grevillea robusta Cunn.: 21.

Cañón; Quercus chrysolepis Liebm.: 24.

Haitian; Catalpa longissima (Jacq.) Sims: 47; SAP: 45.

Red; Quercus rubra L.: 29.

White; Quercus alba L.: 42.

Ochroma lagopus Sw. (= O. pyramidale); Guano de P. R., Balsa, Corkwood,

Coton Fleurs d'Haiti, Maháudéme d'Haiti: 33.

Ocotea acutangula Mez; Louro Tamancao do Brasil: 64 .

canaliculata (Rich.) Mez: White Silverballi of Demerara, Hariraru: 57. arechavaletae Mez; Canela Guaicá do Río Grande do Sul do Brasil: 27. leucoxylon (Sw.) Maza; Laurel Geo-geo de P. R.: 48.

moschata (Meissn.) Mez; Nuez Moscado de P. R., N. del País, N. Cimarrona, Nemocá: 36.

de Panamá; Aguacatillo: 64.

rodiaei (Schomb.) Mez; Demerara Greenheart, Bebeere of Demerara: 91. rubra Mez; Louro Vermelho do Brasil, Determa or Teteruma of Demerara, Grignon d'Cayenne: 57. 
spathulata Mez; Nemoca de P.R.; 29.

Wachenheimii R. Ben.; Silverballi of Demerara, Keriti of Demerara: 48. Ohia Lehua of Hawaii; Metrosideros polymorpha (Gaud.) Rock: 52.

Old Woman's Bitter; Citharexylum fruticosum L.: 43.

Olive, Black; Bucida buceras L.: 75.

Mangrove; Avicenia nitida Jacq.: 23.

Onotillo de Venezuela; Loxopterygium Sagotti Hook f.: 57.

Opepe of Africa; Sarcocephalus diderrichii de Wild.: 32.

Orange; Citrus sinensis Osbeck: 27.

Osage or Mock; Maclura pomifera (Raf.) Schneid.: 92.

Ormosia Krugii Urban; Palo de Mato de P. R., Palo de Peroniá: 35.

Ortegón; Coccoloba rugosa Desf.: 72.

Osage Orange; Maclura pomifera (Raf.) Schneid.: 92.

Pacouri d'Cayenne, Pahoorie or Pakuri of Demerara; Platonia insignis Mart.: 60.

Paddlewood; Aspidosperma excelsum Bth.: 46.

Pajuil de P. R., Anacardium occidentale L.: 43.

Palétuvier d'Haiti; Avicennia nitida Jacq.: 23 or Conocarpus erectus L.: 45.

Palm, African Fan; Borassus aethiopoum Mart.: 27.

Palma Real de P. R.; Roystonea (Oreodoxa) borinquena O.F. Cook: 35.

Palo Amargo de P. R., Rauwolfia tetraphylla L. : 45.

Colorado; Cyrilla racemiflora L.: 45, or Beilschmiedia pendula (Sw.) Nees: 29.

de Aceite; Tetragastris balsamifera (Sw.) Kuntze: 45.

de Cotorra de P. R.; Alchornea latifolia Sw.: 21.

de Goma; Ficus elastica Nois.: 28.

de Guitarra de Cuba; Citharexylum fruticosum L.: 43.

de Hierro de P. R.; Krugiodendron ferreum (Vahl) Urban: 83.

de Leche Chiquito de R. D.; Rauwolfia tetraphylla L.: 45.

de María de P. R.; Calophyllum brasiliense Camb. var. antillanum (Britton) Standl.: 37.

de Mato, o de Peroniá; Ormosia Krugii Urban: 35.

de Muñeca de P. R.; Rauwolfia tetraphylla L.: 45.

de Pan, de Pana de P. R.; Artocarpus altilis (Parkinson) Fosberg: 25.

de Tea; Amyris elemifera L.: $100+$.

Pana, Panapen de P. R.; Artocarpus altilis (Parkinson) Fosberg: 39; SAP:

25.

Paraná Pine; Araucaria angustifolia (Bert.) Kuntze: 46.

Partridgewood: Vouacapoua americana Aubl.: 79.

Pasilla de P. R.; Melia azedarach L.: 22.

Pau Amarello do Brasil; Euxylophora paraensis Huber: 68. 
Branco do Brasil; Phyllostylon brasiliensis Cap.: 40.

d'Arco do Brasil; Tabebuia serratifolia (Vahl) Nicholson: 72.

d'Arco Roxo do Brasil; Tabebuia (or Tecoma) ipe (Mart.) Standl.: 22.

Rei do Brasil; Sterculia pruriens (Aubl.) Schum.: 32.

Roxo do Brasil; Peltogyne Lecointei Ducke: 68.

Santo do Brasil; Zollneria paraensis Huber: 97.

Pear, Alligator; Persea americana Mill.: 48.

Peltogyne Lecointei Ducke; Pau Roxo do Brasil, Brasilian Purpleheart: 68.

pubescens Bentham; Purpleheart, Violet ou Amarante d'Cayenne,

Kuroburelli of Demerara: 72.

porphyrocardia Griseb.; Purpleheart of Trinidad: 60.

Pencil Cedar: Juniperus virginiana L.: 49.

Péndula de P. R.; Citharexylum fruticosum L.: 43.

Blanca de P. R.; Vitex divaricata Sw.: 42.

Persea americana Mill. (= P. gratissima); Aguacate de P. R., Avocado, Alligator Pear, Avocat d'Haiti, Zaboca d'Hati: 48.

Petitia domingensis Jacq.; Capá Blanco de P. R., C. Sabana, C. Sabanero, Fiddlewood, Bastard Stopper, Bois d'Ortie d'Haiti, Chêne Callebassie d'Haiti: 51 .

Philippine Mahogany; Shorea negrosensis Foxw.; 33.

Phyllostylon brasiliensis Cap.; Jatía de Cuba, Baitoa de R. D., Bois Blanc d'Haiti, Cerón de Méjico, Melón de Nicaragua, Sabanero de Colombia, Pau Branco do Brasil: 40.

Picea sitchensis (Bong.) Carr.; Sitka Spruce: 20.

Pienja of Surinam; Vismia macrophylla H.B.K.: 34.

Pignut Hickory; Carya (or Hicoria) glabra (Mill.) Sweet: 34.

Pimenta racemosa (Mill.) J. W. Moore (= Amomis caryophyllata); Ausú de P. R., Ausú, Limoncillo, Pimienta, Bay Rum Tree, Wild Cinnamon, Malagueta, Bois d'Inde Francais: 71.

Pimienta de Cuba; Pimenta racemosa (Mill.) J. W. Moore: 71.

do Brasil; Schinus terebinthefolius Raddi: 28.

Pin d'Australie, Pino Australiano; Casuarina equisetifolia L.: 37.

Pine, Australian; Casuarina equisetifolia L.: 37.

Australian Cypress; Callitris glauca R. Brown: 71.

Brasilian White; Simarouba amara Aubl.: 24.

Northern White; Pinus strobus L.: 55士.

Loblolly; Pinus taeda L.: $22 \pm$.

Scotch; Pinus sylvestris L.: Periferal HEART: 36; central HEART: 34;

SAP: 27.

Southern Yellow Shortleaf; Pinus echinata Mill.: $55 \pm$.

Southern Yellow; Pinus palustris Mill.: 55士. 
West Indian; Pinus occidentalis Sw.: 78.

Western White; Pinus monticola Dougl.: 55士.

Yellow; Pinus ponderosa Laws.: $55 \pm$.

Pino Vermelho do Brasil; Araucaria angustifolia (Bert.) Kuntze (=A. brasiliana A. Rich.): 46.

Pinus echinata Mill.: Southern Yellow Shortleaf Pine: 55土.

monticola Doug.; Western White Pine: 55土.

occidentalis Sw.; West Indian Pine: 78.

palustris Mill.; Southern Yellow Pine: 55士.

ponderosa Laws.; Western Yellow Pine: 55土.

sylvestris L.; Scotch Pine (from Sweden): Periferal HEART: 36; central

HEART: 34; SAP: 27.

strobus L.; Northern White Pine: $55 \pm$.

taeda L.; Loblolly Pine: $22 \pm$.

Piquiá do Brasil; Caryocar brasiliense Camb.: 65, or Aspidosperma australe

Muell. Arg.: 55.

Piratinera guianensis Aubl.; Letterwood, Tibikushi of Demerara: 96.

Pitch Apple; Clusea rosea Jacq.: 27.

Pithecellobium jupunba (Willd.) Urban; Puni of Trinidad: 45.

Pithecellobium racemosum Mez; Angelim Rayado do Brasil, Surinam Snakewood: 64 .

(or Samanea) saman (Jacq.) Benth.; Samán de P. R., Saman of Trinidad, or Cow Tamarind, Cenicero de America Central, Gipio do Brasil, Raintree of Florida, Guango of Jamaica: 57. Specimens of wood from Puerto Rico, Trinidad and Panamá are indistinguishable to the termites.

Platonia insignis Mart.; Bacury do Brasil, Pacouri d'Cayenne, Pahoorie,

Pakuri or Wild Mammee Apple of Demerara: 60.

Plathymenia reticulata Benth.; Vinhatico do Brasil: 93.

Platymiscium trinitatis Benth.; Roble of Trinidad: 45.

Ulei Harms (= P. paraense Huber); Macacahuba do Brasil: 98.

Pleurothyrium cuneifolium Nees (= P. macranthum); Louro Abacate do

Brasil: 49.

Plum, Hog; Spondias mombin L.: 24.

Malabar; Eugenia jambos L.: 22.

Pochote de Costa Rica; Bombacopsis quinatum (Jacq.) Dugand: 44.

Poinciana, Royal; Delonix (or Poinciana) regia (Bojer) Raf.: 20.

Poirier d'Haiti; Erythroxylon areolatum L.: 81.

Poison Ivy; Toxicodendron radicans (L.) Kuntze: SAP: 35.

Poisonwood; Metopium toxiferum (L.) Krug et Urban: 26.

Poix Doux d'Haiti; Inga vera Willd.: 28.

Polisandro de P. R.; Stahlia monosperma (Tul.) Urban: 73.

Pomarrosa de P. R.; Eugenia jambos L.: 22. 
Pomme Rose d'Haiti; Eugenia jambos L.: 22.

Zombi d'Haiti; Hippomane mancinella L.: 31.

Poplar, Yellow; Liriodendron tulipifera L.: 41.

Possentrie of Surinam; Hura creptians L.: 28.

Poui of Trinidad; Tabebuia serratifolia (Vahl) Nicholson: 72.

Pouteria demerarae Sandw.; Asipoko of Demerara: 56.

(or Lucuma) multiflora A. DC.; Jácuna o Acana de P. R.: 46.

Princewood; Cordia alliodora (R. \& .P) Oken: 60.

Prosopis juliflora (Sw.) DC.; Bayahonda de P. R., Mesquite: 50.

Protium decandrum March; Purokai or Kurokai of Demerara: 32.

heptaphyllum March; Beru Vermelho do Brasil, Almecega, Bois Gommier

d'Cayenne, Tacamahaca de Colombia: 59.

Prunus occidentalis Sw.; Almendrón de Hispaniola, Amandier d'Haiti, Cujaní de Cuba: 84.

serotina Ehrh.; Northern Black Cherry: 28.

Pseudotsuga menziesii (Mirb.) Franco; Douglas Fir, Douglas Spruce: 55; SAP: 49.

Psidium guajava L.; Guayaba de P. R., Gouyave d'Haiti, Guava: 32;

SAP: 23.

Pterocarpus draco L. (= P. Ulei Harms); Bébé of Surinam, Sangre de Drago de Mexico, Nicaragua, Colombia y Venezuela: 44.

Puni of Trinidad; Pithecellobium jupunba (Willd.) Urban: 45.

Purokai of Demerara; Protium decandrum March: 32.

Purpleheart, Brasilian; Peltogyne Lecointei Ducke: 68.

Guianan; Peltogyne pubescens Bentham: 72.

Trinidad; Peltogyne porphyrocardia Griseb.: 60 .

Qualea albiflora Warm.; Gronfoloe of Surinam, Mandioqueira do Brasil: 42. dinizii Ducke; Wirsiwirsi Kwalie of Surinam: 46.

sp.; Appelquali of Surinam: 57.

Quaruba do Brasil; Vochysia maxima Ducke: 44.

Quercus alba L.; White Oak: 42.

chrysolepis Liebm.; Cañon Oak: 24.

rubra L.; Red Oak: 29.

Quiebra Hacha de Méjico; Krugiodendron ferreum (Vahl) Urban: 83.

Raintree; Pithecellobium saman (Jacq.) Benth.: 57.

Raisin Marron d'Haiti, R. la Mer; Coccoloba uvifera (L.) L.: 30.

Ramocillo de R. D.; Trichilia pallida Sw.: 84 .

Ratón; Matayba domingensis (DC.) Radlk.: 27.

Rauwolfia tetraphylla L. (=R. nitida); Palo Amargo o Palo de Muñeca de

P. R., Palo de Leche Chiquita de R. D., Cachimbo de P. R., Bois

Lait Femelle d'Haiti, Milkbush: 45.

Rayado, Angelim do Brasil; Pithecellobium racemosum Mez: 64. 
Red Cedar; Juniperus virginiana L.: 49.

Lanan; Shorea negrosensis Foxw.: 33.

Lancewood; Manilkara Huberi (Ducke) Standl.: 81.

Mangrove; Rhizophora mangle L.: 50.

Maple; Acer rubrum L.: 26.

Oak; Quercus rubra L.: 29.

Redgum; Liquidambar styraciflua L.: 29.

Redwood of Trinidad; Guarea guara (Jacq.) P. Wilson: 48.

California; Sequoia sempervirens (D. Don.) Endl.: 54.

Retamo de P. R.; Trichilia hirta L.: 86, SAP: 61.

Rhizophora mangle L.; Mangle Colorado de P. R., Zapatero, Chifle de Vaca, Manglier Rouge d'Haiti, Red Mangrove: 50; SAP: 41.

Robinia pseudoacacia L.; Black Locust: 60.

Roble, Roble Blanco de P. R.; Tabebuia pallida Miers: 34.

de R. D.; Catalpa longissima (Jacq.) Sims: 47; SAP: 45.

of Trinidad; Platymiscium trinitatis Benth.: 45.

Rollinia salcifolia Schlecht.; Araticum do Brasil: 21.

Rose Apple; Eugenia jambos L.: 22.

Rosewood, Yama; Platymiscium Ulei Harms: 98.

Royal Palm; Roystonea borinquena O. F. Cook: 35.

Poinciana; Delonix regia (Bojer) Raf.: 20.

Roystonea (or Oreodoxa) borinquena O.F. Cook; Palma Real de P. R., Royal Palm: 35.

Rubbertree; Ficus elastica Nois.: 28.

Ryania speciosa Vahl; Bois L'agli of Trinidad, Aguacero, Cieza o Guarikama de Venezuela: not repellent but still toxic after 5 year's exposure in the air: $100+$.

Sabicú de Cuba; Lysiloma latisiliqua (L.) Benth.: 72.

Sabina de R. D.; Juniperus gracilior Pilger: 52.

Sabino de P. R., Laurel; Magnolia splendens Urban: 40; SAP: 28.

Sablier d'Haiti; Hura crepitans L.: 28.

Sabanero de Colombia; Phyllostylon brasiliensis Cap.: 40.

Saint Martin d'Cayenne; Andira surinamensis (Bondt.) Splitg.: 77.

Salado de Panamá, Salt-Pond de P. R.; Avicennia nitida Jacq.: 23.

Salie of Surinam, Tetragastris Hostmannii (Engl.) Kuntze: 56.

Salix Humboldtiana Willd. (= S. chilensis): Sauce de P. R., Willow: 20.

(Samanea) Pithecellobium saman (Jacq.) Benth.; Samán de P. R., Cow

Tamarind or Saman of Trinidad, Cenicero de America Central,

Gipio do Brasil, Raintree of Florida, Huango of Jamaica: 57.

Sandalwood of Hawaii; Santalum freycinetianum Gaud.: 66.

Sand-Box; Hura crepitans L.: 28.

Sanders, Yellow; Buchenavia capitata (Vahl) Eichl.: 69; or Zanthoxylum flavum Vahl: 72. 
Sangre de Drago de Mexico, Nicaragua, Colobmia y Venezuela; Pterocarpus draco L.: 44.

Santa María de P. R.; Calophyllum brasiliense Camb., var. antillanum (Britton) Standl.: 37.

Santa María de Panamá; Calophyllum brasiliense Camb.: 42.

Santalum freycinetianum Gaud.; Sandalwood of Hawaii: 66.

Sapium laurocerasus Desf.; Hincha-huevos, Lechesillo, Tabeiba de P.R.: 24.

Sapo Blanco de P. R.; Erythroxylum areolatum L.: 81.

Sapotile d'Haiti; Manilkara bidentata (A. DC.) Chev.: 58.

Sapucaia do Brasil; Lecythis paraensis (Huber) Ducke: 75.

Sapupira do Brasil; Bowdichia nitida Benth.: 78.

Sarabeballi of Demerara; Vouacapoua americana Aubl.: 79.

Sarcocephalus diderrichii de Wild., Opepe of Africa: 32.

Satiné Rubané d'Cayenne; Brosimum paraense Huber: 99.

Satinwood; Zanthoxylum flavum Vahl.: 72.

Brasilian; Euxylophora paraensis Huber: 68.

Indian; Chloroxylum swietenia DC: 95.

Sauce de P. R.; Salix Humboldiana Willd.: 20.

Saúco Cimarrón de P. R.; Turpinia paniculata Vent.: 73.

(Sciacassia) Cassia siamea Lam.; Casia Amarilla de P. R.: 33.

Schinus terebinthefolius Raddi; Pimienta del Brasil: 28.

Sclerolobium melinonii Harms; Djedoe of Surinam, Witte Djedoe: 44.

Scotch lawyer of Trinidad; Clusia rosea Jacq.: 27.

Scotch pine from Sweden; Pinus sylvestris L.; Periferal HEART: 36; Central HEART: 34 ; SAP : 27.

Seagrape; Coccoloba uvifera (L.) L.: 30 .

Serrete of Trinidad; Byrsonima spicata (Cav.) Rich.: 28.

Sequoia sempervirens (D. Don) Endl.; California Redwood: 54.

Shorea negrosensis Foxw.; Tanguile, Red Lanan, Philippine Mahogany: 33.

Shortleaf Pine; Pinus echinata Mill.: 55士.

Siete Cueros; Avicennia nitida Jacq.: 23.

Silver Oak, Australian; Grevillea robusta Cunn.: 21.

Silverballi of Demerara; Ocotea Wachenheimii Mez: 48.

Brown, of Demerara; Licaria canella (Meissn.) Kosterm.: 93.

White, of Demerara; Ocotea canaliculata (Rich.) Mez: 57.

Yellow, of Demerara; Aniba ovalifolia Mez: 94.

Silvia (or Mezilaurus) itauba (Meissn.) Pax.; Itauba do Brasil: 59.

Simaba multiflora Juss.; Hachiballi of Demerara, Simaruba Mirim do Brasil: 23.

Simarouba amara Aubl.; Marupá do Brasil, Simaruba or Simarouba, Acajou Blanc d'Cayenne, Brasilian White Pine: 24. 
Simaruba Mirim do Brasil; Simaba mulliflora Juss.: 23.

Sinche do Brasil; Sorocea ilicifolia Miq.: 38.

Siris, White, Albizzia procera (Roxb.) Benth.: 75.

Sitka Spruce; Picea sitchensis (Bong.) Carr.: 20.

Slagenhout of Surinam; Loxopterygium Sagotti Hook f.: 57.

Sloanea berteriana Choisy; Cacao Motillo de P. R., C. Roseta, Cacaillo, Motillo: 53; SAP: 46.

Snakewood, Surinam; Pithecellobium racemosum Mez: 64.

Soft Wallaba of Demerara; Eperua falcata Aubl.: 56.

Solanum auriculatum Ait.; Fuma Bravo do Brasil: 20.

Sophora chrysophyllata (Salisbury) Seemann; Mamani of Hawaii: 52.

Sorocea ilicifolia Miq.; Sinche do Río Grande do Sul do Brasil, Aracary do Brasil: 38.

Southern Cypress; Taxodium distichum (L.) Rich.: 100-55; SAP: 38.

Yellow Pine; Pinus palustris Mill.: 55 \pm .

Yellow Shortleaf Pine; Pinus echinata Mill.: 55土.

Spanish Cedar; Cedrela odorata L.: 61.

Elm; Cordia alliodora (R. \& P.) Oken: 60.

Spondias mombin L. (= S. lutea); Jobo de P. R., Mombin Franc d'Haiti, Hog Plum: 24.

Spruce, Douglas; Pseudotsuga menziesii (Mirb.) Franco: 55; SAP: 49.

Sitka; Picea sitchensis (Bong.) Carr.: 20.

Stahlia monosperma (Tul.) Urban; Cóbana Negra de P. R., Cóbana, Cóbano, Polisandro, Caobillo: 73.

Sterculia caribaea R. Br.; Mahoe of Trinidad: 26.

pruriens (Aubl.) Schum.; Yahu, Maho, Mahot or Manmaho of Demerara,

Cochon d'Cayenne, Axixa do Brasil, Boia, Pau Rei: 32.

Strangling Fig; Clusea rosea Jacq.: 27.

Sucrin d'Haiti; Inga vera Willd.: 28.

Sucupira do Brasil; Bowdichia nitida Benth.: 78.

Suradan of Demerara; Hyeronima laxiflora Muell. Arg.: 47.

Surinam Snakewood; Pithecellobium racemosum Mez: 64.

Swampmataki of Surinam; Symphonia globulifera L.: 45.

Swartzia leiocalycina Benth.; Wamara of Demerara: 62.

Swietenia macrophylla King; Honduras Mahogany, Caoba Hondureña: 59;

SAP: 50.

mahagoni Jacq.; Caoba de R. D. y P. R., Acajou d'Haiti, West Indian (Dominican or Barbadian) Mahogany: 80; SAP: 58.

(Sylvia Duckei A. Samp.) = Mezilaurus itauba (Meissn.) Taub: Itaúba do

Brasil, Tapinhoam: 49.

Symphonia globulifera L.; Boarwood, Doctor Gum, Chewstick, Yellow 
Mangue of Trinidad, Barillo, Manniballi of Demerara, Mataki or Swampmataki of Surinam, Hooglandmataki, Mani d'Cayenne, Anany do Brasil, Brea-Caspi: 45.

Syncarpia laurifolia Ten; Australian Turpentine: 59.

Tabebuia capitata (Bur. \& K. Schum.) Sandw.; Hakia Greenheart of Demerara: 95.

ipe (Mart.) Standl.; Ipe Roxo do Brasil, Lapacho de Argentina: 22.

pallida (= Tecoma pentaphylla) Miers; Roble de P. R., R. Blanco, White Cedar, West Indian Boxwood: 34.

serratifolia (Vahl) Nicholson, Yellow Poui of Trinidad, or Tecoma conspicua; Pau d'Arco do Brasil: 72.

Tabeiba de P.R.; Sapium laurocerasus Desf.; 24.

Tabernom ou Tabernon d'Haiti; Lysiloma latisiliqua (L.) Benth.: 72.

Tabonuco de P. R.; Dacryodes excelsa Vahl.: 31.

Tacamahaca de Colombia; Protium heptaphyllum March: 59.

Tamancao do Brasil, Louro; Ocotea acutangula Mez: 64.

Tamarindus indica L.; Tamarindo de P. R., Tamarin d'Haiti, Tamarind:

29.

Tanguile of the Philippines; Shorea negrosensis Foxw.: 33.

Tapana of Trinidad, Hyeronima car ibaea Urban: 44.

Tapinhoam, Tapinhoan of Surinam; Mezilaurus itauba (Meissn.) Taub.: 59.

Tapirira marchandii Engl.; Duka of Demerara, Waramai of Surinam, Tapiriri d'Cayenne, Cedrohy, Tatapiririca do Brasil: 24.

Tapaiuna do Brasil; Dicorynia guianensis Amsh.: 44.

Tarana de R. D.; Linociera domingensis (Lam.) Konbl.: 46.

Tatabu of Demerara; Diplotropis purpurea (Rich.) Amsh.: 76.

Tatapiririca do Brasil; Tapirira marchandii Engl.: 24.

Tauroniro of Surinam; Humiria balsamifera Aubl.: 63.

Tavernon d'Haiti; Lysiloma latisiliqua (L.) Benth.: 72.

Taxodium distichum (L.) Rich.: Cypress, Southern C., Bald Cypress; very gummy, fine-grained: 100; gummy: 79; fine-grained, not gummy: 55; SAP: 38.

Tea de P. R.; Amyris elemifera L.: $100+$.

Cimarrona; Matayba domingensis (DC.) Radlk.: 27.

Teak, East Indian; Tectona gradnis L.f.: 80; SAP: 50.

(Tecoma) see Tabebuia.

Tectona grandis L.f.; East Indian Teak: 80; SAP: 50.

Terminalia amazonia (Gmel.) Exel (= T. obovata (R. \& P.) Steud.); Amarillo de Panamá, Guayabón: 70.

arjuna Wight \& Arn.; Arjuna of India: 65. 
catappa L.; Almendro de P. R., Indian or Malabar Almond, Amandier des Indies, Zanmande d'Haiti: 32.

ivorensis Chev.; from West Africa: 43.

Teteruma of Demerara; Ocotea rubra Mez: 57.

Tetragastris balsamifera (Sw.) Kuntze; Masa de P. R., M. Colorado, Palo de Aceite, Amacey de R. D., Bois Cochon d'Haiti: 45.

Hostmanni (Engl.) Kuntze; Haiowaballi of Demerara, Salie of Surinam, Gommier Rouge d'Cayenne, Almesca do Brasil: 56.

Thuja plicata Donn; Western Red Cedar; 44.

Tibikushi of Demerara; Piratinera guianensis Aubl.: 96.

Toporite of Trinidad; Hernandia sonora L.; 26.

Torchwood; Amyris elemifera L.: $100+$.

Tostado de P. R.; Homalium racemosum Jacq.: 71.

Toxicodendron radicans (L.) Kuntze; Poison Ivy: SAP: 35.

(Toxylon) Maclura pomifera (Raf.) Schneid.; Osage Orange, Mock Orange, Bois d'Arc: 92.

Trichilia hirta L.; Cabo de Hacha, Guaita de P. R., Retamo, Jobillo, Molinillo, Broomstick, Mombin Batard d'Haiti, Guayavacón: 86; SAP: 61.

pallida Sw.; Caracolillo de R. D., Gaeta de P. R., Ramoncillo, Bois Arada d'Haiti, Dombou, Marie-Jeanne d'Haiti: 84.

Triplaris surinamensis Cham.; Mierenhout of Surinam, Bois Fourmi d'Cayenne, Formigueiro: 28.

Tsuga canadiensis (L.) Carr.; Hemlock: 38.

Tuliptree; Liriodendron tulipifera L.: 41.

Turpentine, Australian; Syncarpia laurifolia Ten.: 59.

Turpinia paniculata Vent.; Avispillo de P. R., Cedro Hembra, Saúco Cimarrón de Cuba: 73.

Ucar de P. R.; Bucida buceras L.: 75; SAP: 56.

Ucuhúba do Brasil; Virola mycetis Pulle: 28.

Umiry do Brasil; Humiria balsamifera Aubl.: 28.

Uva de Mar, Uvero de P. R.; Coccoloba uvifera (L.) L.: 30.

(Vachellia) Acacia farnesiana (L.) Willd.; Aroma de P. R., Casha, Cashia of Bahamas, Huisache de Méjico: 72.

Vermelho do Brasil, Breu; Protium heptaphyllum March: 59.

Louro; Ocotea rubra Mez: 57.

Violet d'Cayenne; Peltogyne pubescens Benth.: 92.

Vinhatico do Brasil; Plathymenia reticulata Benth.: 93.

Virola mycetis Pulle (=V. surinamensis (Rol.) Warb.): Baboen or Baboonhoodoo of Surinam, Becuiba do Brasil, Ucuhúba do Brasil, Banak or Mahaban (U. S. Trade), Dutch Mahogany: 28.

Vismia macrophylla H.B.K.; Pienja of Surinam, Caopiá do Brasil: 34. 
Vitex divaricata Sw.; Higuerillo de P. R., Lizardwood, Fiddlewood: 42.

Vochysia maxima Ducke ( = V. exima); Quaruba do Brasil, Cedrorana do

Brasil: 44.

tetraphylla (G.F.W. Mey.) DC.; Itebalii of Demerara: 56.

Melinonii Beckman; Wane Kwarie of Surinam: 71.

Vouacapoua americana Aubl.; Acapú do Brasil, Wacapou, Bowhanti of

Surinam, Sarabeballi of Demerara, Partridgewood: 79.

Wabaima of Demerara; Licaria canella (Meissn.) Kosterm.: 93.

Wacapou, Vouacapoua Americana Aubl.: 79.

Wallaba of Demerara, Soft; Eperua falcata Aubl.: 56.

Walnut, Black; Juglans nigra L.: 44.

Wamara of Demerara; Swartzia leiocalycina Benth.: 62.

"Wane" of Surinam (NOT Ocotea rubra): 90.

Wane Kwarie of Surinam; Vochysia Melinonii Beckman: 71.

Waramai of Surinam; Tapirira marchandii Engl.: 24.

Wena Kakeralli of Demerara; Eschweilera Sagotiana Miers: 83.

West Indian Birch; Bursera simaruba (L.) Sarg.: 23.

Boxwood; Tabebuia pallida Miers (Tecoma pentaphylla): 34 .

Cedar; Cedrela odorata L.: 61.

Elm; Guazuma ulmifolia Lam.: 33.

Locust; Hymenaea courbaril L.: 89.

Mahogany; Swietenia mahagoni Jacq.: 80.

Pine; Pinus occidentalis Sw.: 78.

Western Red Cedar; Thuja plicata Donn: 44.

White Pine; Pinus monticola Doug.: 55士.

Yellow Pine; Pinus ponderosa Laws.: 55土.

White Ash; Fraxinus americana L.: 27.

Cedar; Tabebuia pallida Miers (= Tecoma pentaphylla): 34 .

Oak; Quercus alba L.: 42.

Pine; Brasilian; Simarouba amara Aubl.: 24.

-Northern; Pinus strobus L.: 55 \pm .

-Western; Pinus monticola Dougl.: 55土.

Silverballi; Ocotea canaliculata (Rich.) Mez : 57.

Siris; Albizzia procera (Roxb.)Benth.: 75.

Wild Black Cherry, Prunus serotina Ehrh.: 28.

Cinnamon; Pimenta racemosa (Mill.) J. W. Moore: 71.

Cocoplum; Linociera domingensis (Lam.) Knobl.: 46.

Mammee; Clusia rosea Jacq.: 30.

Mammee Apple of Demerara; Platonia insignis Mart.: 60.

Willow, Humboldt's; Salix Humboldtiana Willd.: 20.

Wirsiwirsi Kwalie of Surinam; Qualea dinizii Ducke: 46.

Witte Djedoe of Surinam; Sclerobium melinonii Harms: 44. 
Women's Tongues; Albizzia procera (Roxb.) Benth.: 75.

Yagrumo Macho de P. R.; Didymopanax morototoni (Aubl.) Dene. et Pl.: 27.

Yagrumo Hembra de P. R.; Cecropia peltata L.: 28.

Yama Rosewood; Platymiscium Ulei Harms: 98.

Yahu of Demerara; Sterculia pruriens (Aubl.) Schum.: 32.

Yaruru of Demerara; Aspidosperma excelsum Benth.: 46.

Yedra de P. R., Ficus pumila L.: 29.

Yellow Birch; Betula alleghaniensis Britton: 26.

Cedar; Chamaecyparis nootkatensis (D. Don) Spach: 55.

Mangue of Trinidad; Symphonia globulifera L.: 45.

Pine, Southern; Pinus palustris Mill.: 55士.

-Western; Pinus ponderosa Laws.: $55 \pm$.

Poplar; Liriodendron tulipifera L.: 41.

Poui of Trinidad; Tabebuia serratifolia (Vahl) Nicholson: 72.

Sanders of Florida; Buchenavia capitata (Vahl) Eichl.: 69; or Zanthoxylum flavum Vahl: 72.

Silverballi of Demerara; Aniba ovalifolia Mez: 94.

Zaboca d'Haiti; Persea americana Mill.: 48.

Zanmande d'Haiti; Terminalia catappa L.: 32.

Zanthoxylum (or Fagara) flavum Vahl; Aceitillo de Cuba y P. R., Espinillo de R. D., Yellow Sanders of Florida, Satinwood of British West Indies: 72.

martinicense (Lam.) DC.; Cenizo de P. R., Espino Rubial, Ayua: 27. Zapatero de P. R.; Rhizophora mangle L.: 50; SAP: 41.

Zollneria paraensis Huber; Pau Santo do Brasil, Muirapinima Preta do Brasil: 97.

\section{SUMMARY}

Based on extensive feeding tests with nymphs of the West Indian drywood termite, Cryptotermes brevis Walker, on the woods of nearly 300 species of trees from all parts of the world, it would appear that inherent natural resistance to termite attack resulting from the characteristic presence and abundance in the wood of a specific repellent chemical constituent does not occur in any wood of the Temperate Zone of either the Northern or Southern Hemispheres. Such inherent natural resistance is of comparatively rare occurrence in the semi-Tropics, but has developed in a considerable number of trees of the Tropics of both the Old and the New World.

\section{RESUMEN}

La resistencia natural inherente de algunas maderas a resistir los ataques de la polilla Cryptotermes brevis Walker que daña la madera seca y que es oriunda de las Antillas, consiste en que estas maderas resistentes contienen 
un principio químico específico que repele la polilla. Pruebas extensivas con ninfas de esta especie de polilla, las cuales se pusieron sobre pedacitos de madera de alrededor de 300 especies de árboles procedentes de todas partes del mundo, demostraron que esta acción repelente no ocurre en madera alguna de la zona templada de ambos hemisferios. Esta resistencia natural es comparativamente rara en las regiones semitropicales, pero se encuentra en un número considerable de árboles de los trópicos, tanto del Viejo como del Nuevo Mundo.

\section{LITERATURE CITED}

1. Kalshoven, L. G. E., Survival of Neotermes colonies in infested teak trunks after girdling or felling of the trees, communication of the Forest Research Institute No. 45, reprint from Tectona 43 59-74 (1953), Bogor, Indonesia, 1954.

2. Marchán, F. J., The lignin, ash, and protein content of some Neotropical woods, Caribbean Forester 7 (2) 135-8 (and in Spanish) 150, Río Piedras, P. R., April 1946.

3. Wolcott, George N., The comparative resistance of woods to the attack of the termite, Cryptotermes brevis Walker, Insular Exp. Sta. Bul. 33, pp. 15, Río Piedras, P. R., August 1924.

4. - A list of woods arranged according to their resistance to the attack of the polilla, the dry-wood termite of the West Indies, Cryptotermes brevis Walker, Caribbean Forester 1 (4) 1-10, fig. 2. New Orleans, La., July 1940.

5. - What to do about polilla (in Spanish, "Como Combatir la Polilla"). Agr. Exp. Sta., Univ. P. R. Bul. 68, pp. 29, fig. 4, ref. 5. Río Piedras, P. R., Apr. 2, 1946.

6. - Factors in the natural resistance of woods to termite attack, Caribbean Forester 7 (2) 121-34 (and in Spanish) 139-49, Río Piedras, P. R., April 1946.

7. - A list of woods arranged according to their resistance to the attack of the West Indian dry-wood termite, Cryptotermes brevis Walker, Caribbean Forester 7 (4) 329-36, Río Piedras, P. R., October 1946.

8. - The resistance to dry-wood termite attack of some Central American woods, Caribbean Forester 9 (1) 53-6 (English and Spanish, résumé in French) Río Piedras, P. R., January 1948.

9. -, An index to the termite resistance of woods, Agr. Exp. Sta., Univ. P. R. BuI. 85, pp. 26, ref. 3, Río Piedras, P. R., October 15, 1950.

10. - The termite resistance of pinosylvin and other new insecticides, J. Ec. Ent. 44 (1) 263-4, ref. 6, Menasha, Wis., February 1951.

11. - Stilbene and comparable materials for dry-wood termite control, J. Ec. Ent. 46 (2) 374-5, ref. 5, Menasha, Wis., April 1953.

12. -, Organic termite repellents tested against Cryptotermes brevis Walker, J. Agr. Univ. P. R., 39 (3) p. 118, 1955. 